\title{
Seed Protein of Lentils: Current Status, Progress, and Food Applications
}

\author{
Hamid Khazaei ${ }^{1, *(\mathbb{0})}$, Maya Subedi ${ }^{1, \dagger}$, Mike Nickerson ${ }^{2}$, Cristina Martínez-Villaluenga ${ }^{3}$ (I), \\ Juana Frias ${ }^{3}$ and Albert Vandenberg ${ }^{1}$ \\ 1 Department of Plant Sciences, University of Saskatchewan, Saskatoon, SK S7N 5A8, Canada \\ 2 Food and Bioproduct Sciences, University of Saskatchewan, Saskatoon, SK S7N 5A8, Canada \\ 3 Institute of Food Science, Technology and Nutrition (ICTAN), Spanish National Research Council (CSIC), \\ Jose Antonio Novais 10, 28040 Madrid, Spain \\ * Correspondence: hamid.khazaei@usask.ca or hamid.khazaei@gmail.com; Tel.: +1-306-966-5859 \\ + Current address: Agriculture and Agri-Food Canada, Lethbridge, AB T1J 4B1, Canada.
}

Received: 20 July 2019; Accepted: 30 August 2019; Published: 4 September 2019

\begin{abstract}
Grain legumes are widely recognized as staple sources of dietary protein worldwide. Lentil seeds are an excellent source of plant-based proteins and represent a viable alternative to animal and soybean proteins for food processing formulations. Lentil proteins provide not only dietary amino acids but are also a source of bioactive peptides that provide health benefits. This review focuses on the current knowledge of seed protein, extraction and isolation methods, bioactive peptides, and food applications of lentil protein. Lentil is the most rapidly expanding crop for direct human consumption, and has potential for greater impact as a protein source for food processing applications. Improvements in lentil protein quality, amino acid composition, and processing fractions will enhance the nutritional quality of this rapidly expanding crop globally.
\end{abstract}

Keywords: Lens; protein; amino acid; legume; functionality; bioactive peptides

\section{Introduction}

The importance of food legumes in sustainable agriculture and food security is increasing worldwide. Cultivation of food legumes delivers generous environmental and economic benefits based on their ability to fix nitrogen to replace synthetic fertilizers and thereby reduce greenhouse gas emissions. In contrast with animal-based protein, which has a huge environmental cost, seeds of grain legumes are widely consumed as staple sources of dietary proteins. They are the main source of dietary protein for over one billion people and provide opportunities for greater use in new plant-based protein foods and animal feeds. Protein confers food value, handling properties, and gustatory qualities [1].

Cultivated lentil (Lens culinaris Medik.), one of the ancient crops, is a quick-cooking and nutritious staple legume grown in more than 70 countries and consumed globally in whole, dehulled, and split form [2]. Its seeds are lens-shaped and have a wide range of seed coat colours (green, tan, brown, gray, white, and black) and patterns (marbled, dotted, spotted, complex, and unpatterned [3]). The cotyledons can be yellow, red, or green. Red cotyledon lentils are a source of staple protein and nutritious food in many parts of the Indian subcontinent and eastern Mediterranean regions, where they are consumed mainly in dehulled form as split cotyledons [4]. The major commercial market classes of lentil are red (based on cotyledon colour of dehulled seeds) and green (based on seed coat colour). Large green lentils (with yellow cotyledon) are primarily marketed in Europe, and parts of the Middle East and South America, mostly consumed as whole seeds [5].

Lentil seeds are typically rich in protein, dietary fiber, complex carbohydrates, and essential micronutrients such as iron, zinc, and vitamin B complex [6]. Its seeds also have high antioxidant 
activity compared to other grain legume species mainly due to specific phenolic compounds [7]. Tahir et al. [8] reported only small differences between green and red lentils for protein concentration.

Lentil is in high demand globally and has, by far, the highest growth rate in consumption in comparison to other major pulses (Table 1). Since the beginning of the green revolution (1960-1965), the annual increase of production of faba bean and pea have not kept pace with the growth of the human population ( $2.4 \%$ annual average growth). Chickpea and common bean have increased at the same rate as population growth, while lentil production has grown at more than $10 \%$ per year, second only to soybean. The main reason for the high growth rate is presumed to be the fast cooking time of lentils relative to the other main pulses, in spite of the fact that lentil is often more expensive than most of the other pulses.

Table 1. Global trends of production of selected annual pulse crops in comparison to increases in soybean production and the global human population since 1960.

\begin{tabular}{|c|c|c|c|c|c|c|}
\hline \multirow[t]{3}{*}{ Crop } & \multicolumn{4}{|c|}{ Global Production } & \multicolumn{2}{|c|}{ Global Growth Trends } \\
\hline & \multicolumn{2}{|c|}{ 1960-1965 } & \multicolumn{2}{|c|}{ 2012-2017 } & \multirow[b]{2}{*}{$\begin{array}{l}50 \text { Years \% } \\
\text { Growth }\end{array}$} & \multirow[b]{2}{*}{$\begin{array}{c}\text { Annual \% } \\
\text { Growth }\end{array}$} \\
\hline & $\begin{array}{c}\text { Annual } \\
\text { Mean (Mt) }\end{array}$ & $\begin{array}{l}\% \text { of } \\
\text { Total }\end{array}$ & $\begin{array}{c}\text { Annual } \\
\text { Mean (Mt) }\end{array}$ & $\begin{array}{l}\% \text { of } \\
\text { Total }\end{array}$ & & \\
\hline Lentil & 1.0 & 2.8 & 5.9 & 9.2 & 515 & 10.3 \\
\hline Faba bean & 5.1 & 14.7 & 4.5 & 7.0 & -12 & -0.2 \\
\hline Pea & 10.5 & 30.0 & 13.1 & 20.5 & 25 & 0.5 \\
\hline Chickpea & 6.3 & 17.9 & 12.7 & 19.8 & 104 & 2.1 \\
\hline Common bean & 12.1 & 34.5 & 27.9 & 43.5 & 132 & 2.6 \\
\hline Total pulses ${ }^{1,2}$ & 34.9 & 100 & 64.2 & 90 & 84 & 1.7 \\
\hline Soybean (total) & 28.6 & & 319.0 & & 1115 & 22.3 \\
\hline $\begin{array}{l}\text { Soybean eaten } \\
\text { directly }^{3}\end{array}$ & 10.0 & & 67.0 & & 670 & 13.4 \\
\hline People (1967) ${ }^{4}$ & \multicolumn{2}{|c|}{3465 million } & \multicolumn{2}{|c|}{7600 million } & 119 & 2.4 \\
\hline
\end{tabular}

Nearly one third of the world's population, particularly children in low-income countries, is protein deficient $[10,11]$. The high protein content of lentil, its fast-cooking time, and increased production are contributing to lentil gaining in importance as a staple food for combating human protein malnutrition globally. There is a great need to accelerate genetic improvement for high-yielding lentil cultivars with high quantity and quality of protein. This review focuses on the current knowledge of lentil protein quantity and quality, and the gap between current knowledge, and what knowledge is needed to alleviate nutritional and environmental concerns.

\section{Protein Content}

Like seeds of most cultivated legumes, lentils are a rich source of high-quality protein. Lentil seeds contain on average about $26 \%$ crude protein (see Table 2). Several studies have reported genetic variation for protein content in lentil seeds (Table 2). A Russian bulletin published in 1930 reported that the protein content among lentil varieties varied from $27.5 \%-31.7 \%$ [12]. In the 1970s, an evaluation of an extensive global collection of 1688 accessions of lentil for protein content, reported a greater range of protein content from of $23.4 \%-36.4 \%$ [13]. A subsequent evaluation reported an even wider range when a larger germplasm set (1816 accessions) was investigated [14]. Kumar et al. [15] reported a lower average protein content for lentil with broader variability among lentil species. 
Table 2. Genetic variation and methods used measuring seed the crude protein content in cultivated lentil.

\begin{tabular}{|c|c|c|c|c|}
\hline $\begin{array}{l}\text { Protein Content } \\
\left(\text { Range, \% DM }{ }^{1} \text { ) }\right.\end{array}$ & $\begin{array}{l}\text { Number of } \\
\text { Accessions }\end{array}$ & Environment & Method & Reference \\
\hline $27.5-31.7$ & - & Russia & A micro Kjeldahl Method & Barulina [12] \\
\hline $23.4-36.4$ & 1688 & Egypt & A micro Kjeldahl Method & Hawtin et al. [13] \\
\hline $25.5-28.9$ & 24 & Lebanon and Syria & $\begin{array}{l}\text { NIR }^{2} \text { using a Neotec model } \\
\text { FQA51 A analyzer }\end{array}$ & Erskine et al. [16] \\
\hline $\begin{array}{c}19.6-29.8 \text { and } \\
18.6-30.2\end{array}$ & 829 and 987 & Tel Hadya (Syria) & NIR & Hamdi et al. [14] \\
\hline $23.9-26.3$ & 58 & Australia & $\begin{array}{l}\text { A Kjeldahl } \mathrm{N} \times 6.25 \text { on an } \\
\text { oven-dry basis method }\end{array}$ & Stoddard et al. [17] \\
\hline $23.0-32.0$ & - & - & - & Hedley [18] \\
\hline $24.3-30.2$ & 4 & - & $\begin{array}{c}\text { NIR using a NIR Systems } 6500 \\
\text { analyzer calibrated against the } \\
\text { Dumas method }\end{array}$ & Wang and Daun [19] \\
\hline $23.8-29.3$ & 22 & Saskatoon, Canada & $\begin{array}{l}\text { A Dumus Combustion method to } \\
\text { determine Nitrogen percentage } \\
\text { using a method in } 46-30.01\end{array}$ & Tahir et al. [8] \\
\hline $22.7-31.88$ & 46 & Turkey & $\begin{array}{l}\text { A Kjeldahl method AOAC, } \\
\text { Official Method of Analysis }\end{array}$ & Karaköy et al. [20] \\
\hline $21.8-27.1$ & 14 & Italy & A Kjeldahl method & Zaccardelli et al. [21] \\
\hline $25.3-29.3$ & 35 & Saudi Arabia & $\begin{array}{l}\text { A Kjeldahl method of Association } \\
\text { of Official Analytical Chemists } \\
\text { (AOAC) }\end{array}$ & Alghamdi et al. [22] \\
\hline $24.6-30.0$ & 23 & Multiple & Multiple methods & Heuzé et al. [23] \\
\hline $10.5-27.1$ & 45 & India & A Kjeldahl method & Kumar et al. [15] \\
\hline
\end{tabular}

${ }^{1} \mathrm{DM}$, dry matter. ${ }^{2} \mathrm{NIR}$, near-infrared reflectance spectroscopy.

\section{Lentil Seed Storage Proteins}

Seed storage proteins of lentil are located in the cotyledons, representing up to $80 \%$ of total proteins. Seed storage proteins primarily provide nitrogen, carbon, and sulphur during seed germination and seedling growth and development [24]. They are also involved in plant defence mechanisms, e.g., for bruchids in legumes [25], and in antimicrobial activity (reviewed in Cândido et al. [26]). Seed storage proteins are classifiable based on their solubility in different solvents. The first report of protein components in lentil was that of Osborne and Campbell [27] who isolated globulins from lentil seeds. Later, Danielson [28] grouped the globulins into two classes, 7S (vicilin and convicilin-type) and 11S (legumin-like) based on their sedimentation coefficients. The predominant lentil storage proteins, similar to other legume species, are salt-soluble globulins and water-soluble albumins (Table 3). Both the globulins and albumins of lentils are heterogeneous [29-31]. Legumes in general contain relatively large concentrations of globulins [32]. The 7S/11S ratio is an important characteristic for describing seed nutritional quality [33] and is reported to be very high in lentil, close to three [31]. The ratio of three in lentil is twelve-fold higher than in seeds of pea and Medicago truncatula. These results suggest that lentil may meet certain criteria for specific end uses based on protein quality characteristics. 
Table 3. Summary of reported analyses of cultivated lentil seed storage protein fractions (\%) based on their solubility in different solvents.

\begin{tabular}{ccccc}
\hline Salt Soluble & Water Soluble & Acid Soluble & Ethanol Soluble & Reference \\
\hline Globulins & Albumins & Glutelins & Prolamins & \\
\hline $44 \%$ & $26 \%$ & $20 \%$ & $2 \%$ & Saint-Clair [34] \\
$47 \%$ & $4 \%$ & $15 \%$ & $3 \%$ & Bhatty et al. [35] \\
$54 \%$ & $20 \%$ & - & - & Bhatty [36] \\
$42 \%$ & $11 \%$ & $47 \% 2$ & - & Neves and \\
$27 \%$ & $61 \%$ & $3 \%$ & $2 \%$ & Lourenco [32] \\
$70 \%$ & $16 \%$ & $11 \%$ & $3 \%$ & Sulieman et al. [37] \\
\hline
\end{tabular}

${ }^{1}$ About a quarter of the meal proteins were not solubilized by the solvents. ${ }^{2}$ Prolamins, glutelins, non-nitrogen protein, and residual nitrogen. The quantitative data presented in this table are based on peptide bands and their molecular weight on SDS-PAGE (sodium dodecyl sulfate-polyacrylamide gel electrophoresis). The albumin, glutelin, and prolamin fractions contained 13,4 , and 10 polypeptides, with molecular weight (MW) of about 20, $17-46$, and 16-64 kDa, respectively [39]. Globulins contain legumin- and vicilin-like proteins. The native globulin, with a molecular weight of $375 \mathrm{kDa}$, has twelve polypeptides and MW ranging from 14-61 kDa [32].

Table 3 shows the reported high variation for each specific lentil seed storage fraction, particularly for albumins. The variation may reflect genotypic variation in storage protein profiles, or the extraction conditions employed in each individual study. For instance, Bhatty et al. [35] reported that, in addition to the albumin proteins, direct extraction of lentil meal with water solubilizes some non-protein nitrogen and may solubilize some salt-soluble proteins. Exhaustive extraction of the meal with a salt solution followed by precipitation of the salt-soluble proteins by dialysis provides a better estimate of this protein fraction.

Metabolic proteins (enzymes and structural proteins) are another major type of protein found in lentil seeds. Several non-storage proteins such as enzymes involved in DNA replication, proteins involved in various physiological processes and house-keeping proteins have been identified [31]. Sulieman et al. [37] showed that lentil protein fractions are altered quantitatively and qualitatively due to cooking, and the effect was most pronounced in prolamin fractions.

\section{Amino Acids (AA)}

Cultivated lentil proteins, like those of other grain legumes, are rich in endogenous amino acids (arginine, aspartic and glutamic acids, and leucine-more than half of total AA), low in some essential amino acids (EAA) like threonine, methionine, phenylalanine, tryptophan, histidine, valine, isoleucine, and leucine-excluding lysine), and poor in sulphur-containing amino acids (methionine and cysteine, see Table 4). For the WHO/FAO/United Nations University [40]. AA requirement patterns also showed low levels of both sulphur-containing amino acids and tryptophan in lentil seeds.

Table 4. Amino acid composition \pm standard deviation $(\mathrm{g} / 16 \mathrm{~g} \mathrm{~N})$ in seeds of six major grain legumes.

\begin{tabular}{cccccccc}
\hline Amino Acid & Lentil $^{\mathbf{1}}$ & Faba Bean $^{\mathbf{2}}$ & Pea $^{\mathbf{3}}$ & Soybean $^{\mathbf{4}}$ & Chickpea $^{\mathbf{5}}$ & Common Bean $^{\mathbf{6}}$ & SEM $^{\mathbf{7}}$ \\
\hline Alanine & $4.2 \pm 0.4$ & $4.1 \pm 0.2$ & $4.3 \pm 0.2$ & $4.2 \pm 0.3$ & $4.1 \pm 0.5$ & $3.8 \pm 0.3$ & 0.07 \\
Arginine & $7.8 \pm 1.0$ & $10.2 \pm 1.1$ & $8.2 \pm 0.7$ & $7.4 \pm 0.6$ & $9.0 \pm 1.2$ & $6.5 \pm 0.7$ & 0.51 \\
Aspartic acid & $10.7 \pm 1.1$ & $11.0 \pm 1.6$ & $11.3 \pm 0.5$ & $11.3 \pm 0.7$ & $11.6 \pm 0.7$ & $10.6 \pm 1.3$ & 0.15 \\
Cysteine & $1.1 \pm 0.3$ & $1.4 \pm 0.3$ & $1.3 \pm 0.3$ & $1.3 \pm 0.4$ & $1.3 \pm 0.1$ & $1.1 \pm 0.2$ & 0.06 \\
Glutamic acid & $16.1 \pm 2.6$ & $16.7 \pm 2.2$ & $16.4 \pm 0.7$ & $17.8 \pm 1.2$ & $16.8 \pm 2.2$ & $15.6 \pm 2.1$ & 0.31 \\
Glycine & $4.1 \pm 0.7$ & $4.3 \pm 0.2$ & $4.3 \pm 0.2$ & $4.1 \pm 0.4$ & $3.6 \pm 0.6$ & $4.2 \pm 0.5$ & 0.10 \\
Histidine & $2.4 \pm 0.5$ & $2.6 \pm 0.2$ & $2.3 \pm 0.3$ & $2.6 \pm 0.1$ & $2.6 \pm 0.5$ & $2.7 \pm 0.2$ & 0.05 \\
Isoleucine & $4.1 \pm 0.5$ & $4.0 \pm 0.4$ & $4.1 \pm 0.5$ & $4.4 \pm 0.6$ & $3.8 \pm 0.4$ & $4.2 \pm 0.3$ & 0.09 \\
Leucine & $7.2 \pm 0.4$ & $7.7 \pm 0.6$ & $7.3 \pm 0.8$ & $7.5 \pm 0.4$ & $7.0 \pm 0.4$ & $7.5 \pm 0.7$ & 0.11 \\
Lysine & $6.7 \pm 0.6$ & $6.4 \pm 0.1$ & $7.6 \pm 1.2$ & $6.4 \pm 0.6$ & $6.5 \pm 0.8$ & $6.3 \pm 0.5$ & 0.19 \\
\hline
\end{tabular}


Table 4. Cont.

\begin{tabular}{|c|c|c|c|c|c|c|c|}
\hline Amino Acid & Lentil $^{1}$ & Faba Bean $^{2}$ & Pea $^{3}$ & Soybean $^{4}$ & Chickpea $^{5}$ & Common Bean $^{6}$ & SEM $^{7}$ \\
\hline Phenylalanine & $5.0 \pm 0.6$ & $4.2 \pm 0.2$ & $4.8 \pm 0.5$ & $4.8 \pm 0.3$ & $5.5 \pm 0.5$ & $4.4 \pm 0.7$ & 0.18 \\
\hline Serine & $4.7 \pm 0.7$ & $4.6 \pm 0.4$ & $4.9 \pm 0.5$ & $5.1 \pm 0.5$ & $4.8 \pm 0.9$ & $5.2 \pm 0.7$ & 0.08 \\
\hline Threonine & $3.7 \pm 0.4$ & $3.5 \pm 0.2$ & $3.8 \pm 0.3$ & $3.9 \pm 0.4$ & $3.7 \pm 0.6$ & $4.0 \pm 0.2$ & 0.07 \\
\hline Tryptophan & $0.8 \pm 0.1$ & $0.9 \pm 0.1$ & $1.2 \pm 0.6$ & $1.4 \pm 0.3$ & $1.0 \pm 0.1$ & $1.1 \pm 0.4$ & 0.09 \\
\hline Valine & $4.7 \pm 0.4$ & $4.4 \pm 0.4$ & $4.5 \pm 0.5$ & $4.7 \pm 0.5$ & $4.0 \pm 0.4$ & $4.9 \pm 0.5$ & 0.13 \\
\hline
\end{tabular}

${ }^{1}$ Mean of data extracted from Kahn and Baker [41]; Chatterjee and Abrol [42]; Bhatty et al. [35]; Sosulski [43]; Bhatty and Christison [44]; Shekib et al. [45]; Pirman et al. [46]; Porres et al. [47]; Zia-Ul-Haq et al. [48], and Grela et al. [7]. ${ }^{2}$ Mean of data extracted from Kaldy and Kasting [49]; Bhatty and Christison [44]; Lisiewska et al. [50]; Schumacher et al. [51], and Grela et al. [7]. ${ }^{3}$ Mean of data extracted from Bhatty and Christison [44]; Leterme et al. [52]; Pownall et al. [53]; Schumacher et al. [51], and Grela et al. [7]. ${ }^{4}$ Mean of data extracted from Kuiken et al. [54]; Tkachuk and Irvine [55]; Cho and Bayley [56]; Cavins et al. [57]; Wang and Cavins [58]; Zarkadas et al. [59], and Sotak-Peper et al. [60]. ${ }^{5}$ Mean of data extracted from Wang and Daun [61]; Alajaji and El-Adawy [62]; Wang et al. [63]; El-Beltagi et al. [64], and Grela et al. [7]. ${ }^{6}$ Mean of data extracted from Wu et al. [65]; Słupski [66] and, Grela et al. [7]. The mean of AA for all species includes data from https://www.feedtables.com. ${ }^{7}$ Standard error of means.

Lentil has relatively a similar AA profile in comparison to other grain legume species (Table 4). Principal component analysis (PCA) of the AA from the studied legume species (Figure 1) revealed lentil and pea have very similar AA composition compared to other studied species and were characterized by high lysine. Principal component 1 alone explained over $99 \%$ of total variation. Faba bean was characterized by high arginine content. The PCA analysis also revealed that AA were grouped based on their AA amount. The average AA composition of M. truncatula was found to be very close to pea in various growing conditions [67]. Soybean and common bean had also similar AA profile (Figure 1).

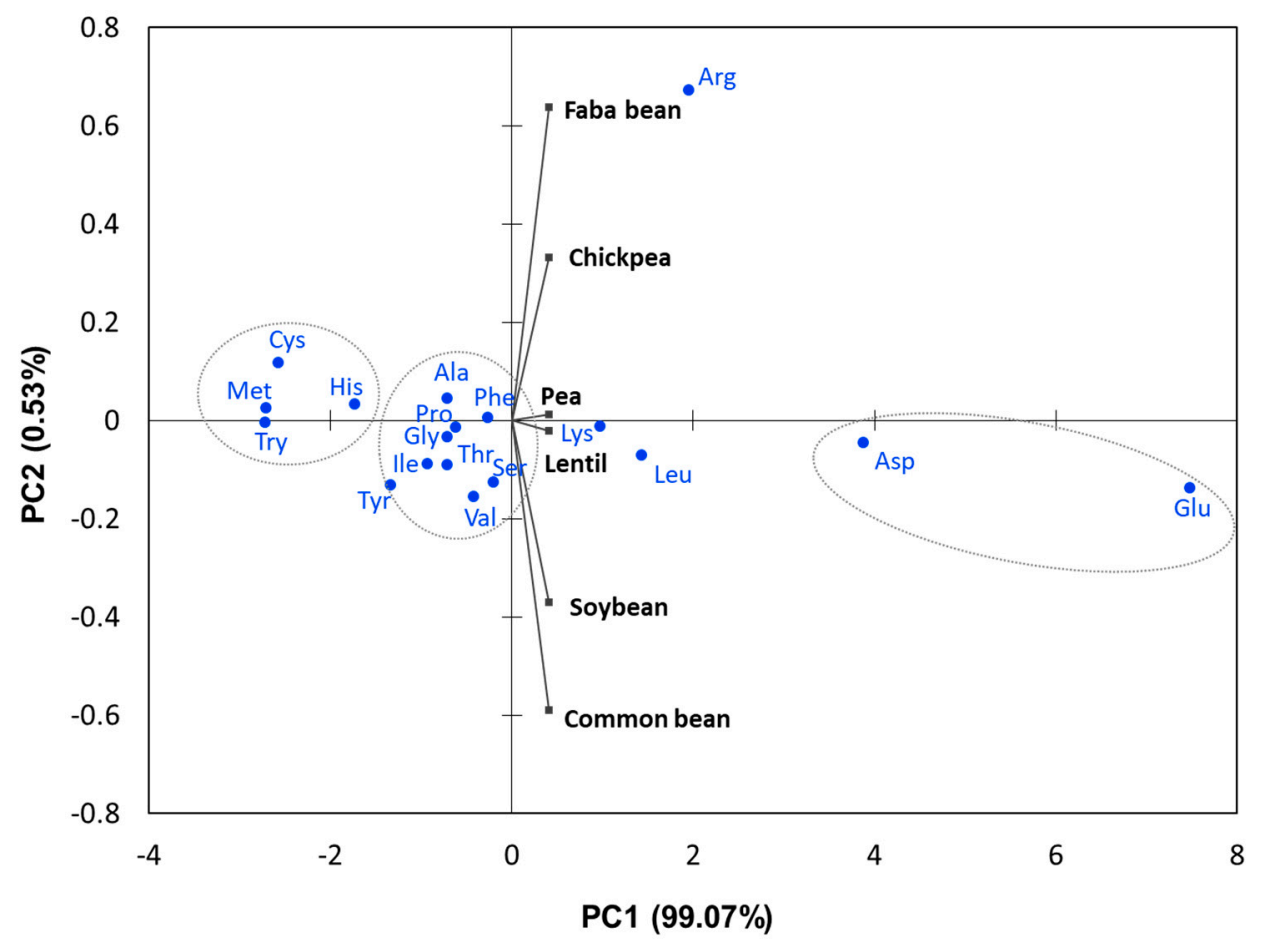

Figure 1. Principal component analysis (PCA) of amino acid data (meta-analysis) from Table 2. The biplot shows amino acid data and legume crops as vectors. Vectors that are close together are correlated in terms of the observed amino acid pool for each crop. PCA analysis was employed to illustrate relationships between amino acids and legume species using the $\mathrm{R}$ statistical package (R Development Core Team, 2018, www.Rproject.org). 
Lentil protein is low in methionine $(0.9 \%)$, especially when compared with animal-based proteins $(>2.2 \%,[68])$. Methionine is typically lower in plant-based proteins compared with animal-based proteins [69], and in general, plant proteins are only low in a few EAA. Combining plant proteins that are lower in lysine and higher in methionine (e.g., wheat, rice and hemp) with plant proteins that are higher in lysine and lower in methionine (grain legumes, including lentil) may balance the anabolic properties of plant-based protein intake [68].

The main non-protein AAs in lentil seeds are trigonelline [70], erythro- $\gamma$-hydroxyarginine 2(S), 4(R)-4-hydroxyarginine [71], $\gamma$-hydroxyarginine, $\gamma$-hydroxyornithine, and homoarginine [72].

\section{Wild Lentil Taxa Protein Properties}

The genus Lens has seven closely related taxa, namely L. culinaris (cultivated lentil), L. orientalis, L. tomentosus (primary gene pool); L. odemensis, L. lamottei, (secondary gene pool); L. ervoides (tertiary gene pool); and L. nigricans (quaternary gene pools) [73]. Bhatty [74] reported similar protein content for three wild lentil species from different gene pools (L. orientalis, L. ervoides, and L. nigricans) in comparison to cultivated lentil (range of $24.2 \%-26.2 \%)$. However, a much wider range $(18.1 \%-32.7 \%$ ) for protein content was reported recently for L. orientalis, L. tomentosus, L. odemensis, L. ervoides, and L. nigricans. The highest protein content was found in the L. ervoides accession, ILWL 47, with 32.7\% protein content [15]. L. ervoides accessions also showed the highest variation compared to other studied species.

With respect to the storage protein fractions, all the wild species except $L$. nigricans had greater amounts of albumin and globulin than cultivated lentil. L. nigricans also had higher non-protein nitrogen than L. orientalis and L. ervoides [74]. In contrast, Rozan et al. [70] findings indicated that $L$. ervoides contained less non-protein AA than other Lens species.

The protein AA composition profiles of wild lentil species L. orientalis, L. ervoides, and L. nigricans were identical and similar to cultivated lentil [74]. A more recent study revealed that $L$. orientalis seeds had relatively higher AAsthan the other Lens species, including cultivated lentil [70].

\section{Anti-Nutritional Factors Affecting Lentil Protein}

Nutritional value of seed protein is determined primarily by the amount of anti-nutritional factors (ANFs) and the AA digestibility [75]. Removal of ANFs is necessary to improve nutritional quality. In general, whole lentils are low in ANFs. Lentil has relatively high tannin content compared to other grain legumes [7]. Tannins are primarily located in the seed coat and can be removed by processing (e.g., dehulling). Tannins can reduce protein digestibility by reacting with lysine and methionine and making them available in a smaller amount during digestion [76]. Zero tannin lentils are now available [77]. The zero tannin trait in lentil is controlled by a single recessive gene ( $\tan$ ) that results in a phenotype characterized by green stems, white flowers, and thin and transparent seed coats, a consequence of a major reduction in most of the seed coat polyphenols [78].

Trypsin inhibitors are low molecular weight proteins found in a wide range of plants including legumes [79] that irreversibly inhibit physiological trypsin enzyme. They induce hypersecretion of pancreatic enzymes (trypsin), thereby stimulating pancreatic hypertrophy, which leads to reduced digestion and absorption of amino acids and, hence, their bioavailability [79-81]. The bioavailability changes result in lower retention of nitrogen and sulphur, and impaired growth [82]. Trypsin inhibitor content of lentil is significantly lower than other grain legumes excluding pea (e.g., [83-85]). The trypsin inhibitors can be markedly reduced by soaking, cooking, and germination of lentil seeds [85].

\section{Environmental Effects on Seed Proteins}

The seed filling stage involves mobilization and transport processes required for importing various seed constituents. Environmental stresses (such as drought) can impair seed filling due to the disruption of metabolic pools downward of sucrose in starch synthesis [86], resulting in an increase of seed protein. Studies in many crops report increased content of seed protein in response to drought 
stress, for example, in wheat $[87,88]$, chickpea [89], and soybean [90,91]. In contrast, some other studies reported reduction of protein content in response to other environmental stresses [92]. These differences may be attributable to the intensity and duration of stresses imposed on plants. Additionally, at the beginning of seed filling stage under unfavorable conditions, proteins related to protection against stress are probably synthesized (increasing protein content), whereas a reduction in protein content is due to their hydrolysis and degradation.

In lentil, heat stress is reported to reduce protein content $(26 \%-41 \%$ [93]). Heat stress also inhibited the accumulation of globulins, albumins, glutelins, and prolamins. Excluding proline, glycine, alanine, isoleucine, leucine, and lysine, which increased under heat stress, the rest of the amino acids significantly decreased [93]. The decrease in lentil storage proteins and most of the AA composition profile resulting from high temperature stresses may be explained by the inactivity of biosynthetic enzymes [94], and by changes in nitrogen content [95]. The increase in some AA (e.g., proline and glycine) under stress conditions may be the effects of osmoregulation mechanisms [96]. Further investigation is required to determine the impacts of environmental stresses on protein content, protein fractions and AA composition, especially in legume crops such as lentil.

\section{Yield and Protein Relationships and Stability}

For lentil breeders, a major challenge is the simultaneous increase of both yield and protein content while maintaining progress in the development of resistance to biotic and abiotic stresses. Hamdi et al. [14], using two large sets of ICARDA lentil germplasm $(829+987$ accessions), found negative correlation between seed protein content and seed yield. They also reported high heritability (0.84) for protein content. Erskine et al. [16] showed the same trend in lentil for a smaller germplasm set. Later, Stoddard et al. [17] showed lack of correlation between protein and yield. More recently, Lizarazo et al. [97] reported negative relationships between protein concentration and seed yield in 14 lentil cultivars grown in a boreal growing environment. This may suggest that independent selection of both characters during breeding is challenging, i.e., the rate of gain in one trait being reduced by that in the other.

Barulina [12] indicated that the protein content varied little across locations among lentil accessions. Similar results are reported for lentil from different authors $[17,35,97]$ and for other legume crops (e.g., $[67,98])$. These observations suggest there is low $\mathrm{G} \times \mathrm{E}$ interaction for protein content and AA composition. This supports the hypothesis that the nitrogen fixing ability of legumes makes their protein concentration relatively stable across environments [17]. It is known that the protein content of the seed is highly affected by soil nitrogen level, so in legumes the Rhizobium bacteria may greatly enhance the percentage seed protein. For example, Ivanov [99] reported large differences between seed protein content of non-inoculated and inoculated chickpea plants, $12.6 \%$ and $31.2 \%$, respectively.

\section{Agronomic Protein Yield of Lentil}

Protein yield is calculated as protein fraction $\times$ grain yield. In lentil, a value of $0.33 \mathrm{t} \mathrm{ha}^{-1}$ protein was reported by Erskine et al. [16]. Khatun et al. [100] reported $0.2 \mathrm{t} \mathrm{ha}^{-1}$ for lentil protein yield grown in Bangladesh. Lizarazo et al. [97] reported protein yield of $0.4 \mathrm{t} \mathrm{ha}^{-1}$ for lentil grown in northern Europe, which was less than that for faba and $\left(1.6 \mathrm{t} \mathrm{ha}^{-1}\right)$ and narrow-leafed lupin $\left(1.1 \mathrm{t} \mathrm{ha}^{-1}\right)$. In pea, protein yield has been reported at $0.7 \mathrm{tha}^{-1}$ [101] and $0.9 \mathrm{tha}^{-1}$ [102].

The potential protein yield of lentil in specific environments has most likely not been fully explored due to limitations imposed by the narrow genetic base of most lentil breeding programs, which are not able to fully exploit the genetic potential due to adaptation bottlenecks. With the recent increasing emphasis on genomics within breeding programs, it may be possible to more fully explore the genetic potential for improvements in protein quantity and quality. The AGILE (Application of Genomic Innovation in the Lentil Economy) project (https://knowpulse.usask.ca/study/2675314), which evaluated phenotypic influences of temperature and photoperiod of 324 diverse lentil genotypes in replicated trials in the three main global agro-ecological regions of lentil production, may provide 
deeper understanding of aspects of protein quality and protein yield potential of lentil. Genomic information of the 324 sequenced lentil genotypes grown across the three major agro-ecological zones for lentil production may further provide the understanding of the underlying genetics of protein quality and protein yield in lentil.

\section{Seed Crude Protein Determination in Lentil}

The two most prevalent protein determination methods, Kjeldahl and Dumas combustion, are commonly used for grain and seed protein analysis in crops including lentil $[12,17,19]$. The methods rely on the release of nitrogen from the amine groups found in the peptide bonds of the polypeptide chains of protein. The traditional Kjeldahl method is based on oxidation to release nitrogen, while the Dumas combustion method breaks down the bonds in the peptide chains, permitting the release of nitrogen through complete combustion of the sample [103]. The released nitrogen content is multiplied by a factor to measure protein content [104]. The factor varies between crop species depending on nitrogen content of protein between $13 \%$ and $19 \%$. For pulses, the average nitrogen $(\mathrm{N})$ content of protein was found to be about $16 \%$, which led to use the calculation $\mathrm{N} \times 6.25$ to convert nitrogen content into protein content [105].

In a series of experiments, most researchers employed a Kjeldahl method to determine crude protein in lentil. For example, Barulina [12] and Hawtin et al. [13] determined seed protein content in lentil accessions using a macro-Kjeldahl (Table 2). Recently, different versions of a modified Kjeldahl method were adopted to measure protein content in lentil seeds [15,17]. Although the Kjeldahl method was more precise and frequently used to analyze protein, this method is under threat by the challenge of safer, clearer, and faster instruments employed in the Dumas Combustion method [103] which resulted in faster, safer, and more reliable data for protein content in seeds compared to the Kjeldahl method. The Dumas combustion method was adopted to determine lentil seed protein content by Tahir et al. [8] when they compared lentil protein with other pulses in Canada using AACC (American Association of Cereal Chemists) method 46-30 to determine percent crude protein $(\mathrm{CP} ; \mathrm{N} \times 6.25)$ through the use of a LECO CNS-2000 Nitrogen Analyzer (LECO Corporation, St. Joseph, MI, USA, Model No. 602-00-500). A rapid test method using near-infrared (NIR) spectroscopy as a complement to current protein determination using either the Kjeldahl or Dumas combustion method was also successfully applied to estimate protein content in lentil seeds using a different model of analyzer [14,16,19]. Protein measured through NIR was validated by calibrated value against measurements obtained through either Kjeldahl or Dumas methods using representative samples. The NIR method was found to be a rapid, low cost, and green complementary technique as it does not use chemicals and reagents [106]. NIR is a useful high throughput method for estimating protein content for lentil breeding programs if calibrated curves are used to validate the method. The value of protein concentration using three different methods in lentil research are illustrated in Table 2.

\section{Protein Isolation Methods and Extraction}

Lentils are traditionally consumed as whole seed, dehulled split seeds, or as footballs (cotyledons remain attached) in salads and soups or stews commonly known as 'dal' [4,107]. Diverse and novel applications are needed to identify ways to increase the use of lentils in the food industry. Nutritional components in lentil seeds such as dietary fiber, starch and protein concentrates or isolates can be extracted and separated [38]. These can be used as ingredients in the preparation of diverse value-added food products.

Isolation or separation of seed proteins from pulses is possible using wet or dry processes [108-110]. Dry processes, such as pin milling and then air classification, are designed to differentiate fractions of starch and protein based on size and density. Air classification separates milled lentils into a light to fine fraction (the protein concentrate) and a heavy or coarse fraction (the starch concentrate) [111,112]. Protein concentrates produced by air classification through dry processes generally contain $38 \%-68 \%$ protein $[113,114]$. In the past, air classification processes were well adapted to extraction of isolates of 
lentils and peas because of the large diameter and fairly uniform distribution of starch granules [112]. The dry method is a relatively easy and simple process, however, efficacy of separation is not high enough to yield high protein concentration. Currently, the wet method for extraction is more widely adopted for legume protein extraction [108]. The extraction of pulse proteins through wet methods may be relatively easy and reliable, as they are highly soluble under alkaline and acidic conditions. In wet methods, protein is extracted by solubilization in an alkaline solution by dispersing pulse flour in water at $\mathrm{pH} 8-10$, followed by stirring of the dispersion. Then, the insoluble material is removed by centrifugation and proteins are recovered by adjusting the, supernatant $\mathrm{pH}$ to a value around 4.5 , where proteins are precipitated isoelectrically. The precipitation is usually carried out at the isoelectric point of the protein at which its solubility is the lowest, which for lentil protein is around $\mathrm{pH}$ 4.5. The final concentrate or isolated protein is then dried using spray-drum or freeze-drying methods [115]. Lentil isolates prepared with an alkaline process yield overall $80 \%$ of protein $[108,116,117]$. Many researchers have used various wet fractionation methods to isolate lentil protein $[108,109,116-118]$ under single or multiple isoelectric $\mathrm{pH}$ conditions using diluted sodium hydroxide [36] (Table 5). For example, Boye et al. [38] reported they extracted lentil protein isolates from red and yellow cotyledon lentils using isoelectric precipitation at $\mathrm{pH} 9$ and $25^{\circ} \mathrm{C}$ using a 1:10 solid to solvent ratio, resulting in protein concentrates between $78.2 \%$ and $88.6 \%$. Similarly, Joshi et al. [119] extracted lentil protein isolate by alkaline extraction at $\mathrm{pH} 8$ using 1:10 solid to solvent ratio at room temperature when they studied physicochemical characteristics of the isolated protein that obtained from three drying methods (freeze, spray and vacuum drying). In another study, Kaur et al. [120] revealed that yield of lentil protein isolate ranged from $81.7 \%-83.5 \%$ for Indian cultivars when they performed the protein isolation using isoelectric precipitation $\mathrm{pH}$ 4.5. In contrast, Alsohaimy et al. [117] found the highest protein recovery ( $93 \%$ and $100 \%$ ) from lentil isolate at isoelectric $\mathrm{pH}$ of 12 with ammonium sulphate and alcohol precipitation solvent, with a 5:100 solid to solvent ratio. They compared seven different $\mathrm{pH}$ values ranging from 6 to 12 with three different protein recovery methods-isoelectric precipitation, ammonium sulphate preparation, and alcohol precipitation. Similarly, Lee et al. [115] reported pH 9 at $30{ }^{\circ} \mathrm{C}$ as the optimum extraction condition for green lentil that yielded $56.6 \%$ protein, and $\mathrm{pH} 8.5$ at $35^{\circ} \mathrm{C}$ for red lentil that yielded $59.3 \%$ protein when they compared five $\mathrm{pH}$ levels (distilled water, $\mathrm{pH}$ $8,8.5,9$, and 9.5) and four temperatures $\left(22,30,35\right.$, and $\left.40^{\circ} \mathrm{C}\right)$. Johnston et al. [121] used a modified isoelectric precipitation procedure by adjusting initial $\mathrm{pH}$ to 9 initially and then collecting lentil protein isolate at $\mathrm{pH} 4.6$ with 1:10 solid to solvent ratio. Cultivar, particle size of the flour, type of solubilizing agent, temperature, and $\mathrm{pH}$ of extraction medium influenced the protein yield and quality [110].

Table 5. Conditions for wet fractionation methods for extraction of lentil protein in six recent studies.

\begin{tabular}{|c|c|c|c|}
\hline Conditions for Lentil Protein Extraction & $\%$ Protein Yield & $\%$ Protein in Final Extracts & Reference \\
\hline $\begin{array}{l}\mathrm{pH}: 6,7,8,9,10,11 \text {, and } 12 \\
\quad \text { Temperature: room } \\
\text { Solid to solvent ratio: } 5: 100\end{array}$ & 80.0 & 21.5 & Alsohaimy et al. [117] \\
\hline $\begin{array}{c}\mathrm{pH}: 8,8.5,9,9.5 \\
\text { Temperature: } 22{ }^{\circ} \mathrm{C}, 30{ }^{\circ} \mathrm{C}, 35^{\circ} \mathrm{C} \text {, and } 40{ }^{\circ} \mathrm{C} \\
\text { Solid to solvent ratio: } 1: 10\end{array}$ & $56.6-59.3$ & - & Lee et al. [115] \\
\hline $\begin{array}{c}\text { pH: } 9 \\
\text { Temperature: } 25^{\circ} \mathrm{C} \\
\text { Solid to solvent ratio: } 1: 10\end{array}$ & $50.3-69.1$ & - & Boye et al. [38] \\
\hline $\begin{array}{c}\text { pH: } 8 \\
\text { Temperature: room } \\
\text { Solid to solvent ratio: } 1: 10\end{array}$ & - & - & Joshi et al. [119] \\
\hline $\begin{array}{c}\text { pH: } 4.6 \\
\text { Temperature: room } \\
\text { Solid to solvent ratio: } 1: 10\end{array}$ & 82.0 & 14.5 & Johnston et al. [121] \\
\hline $\begin{array}{c}\text { pH: } 8,9 \text { and } 10 \\
\text { Temperature: room } \\
\text { Solid to solvent ratio: } 1: 10\end{array}$ & $70.3-85.7$ & $12.3-16.5$ & Jarpa-Parra et al. [122] \\
\hline
\end{tabular}


In addition to air classification, a new emerging dry fractionation method, triboelectrostatic separation has emerged recently as a novel solvent-free approach to separate protein isolates in the food industry [123-125]. This method relies on differences in dielectric properties of flour particles instead of their size and density. The basic principle of this technique is that proteins can be electrostatically charged more than carbohydrates, because of the ionizable $\mathrm{N}$-terminus and $\mathrm{C}$-terminus groups in their amino acid residues [126]. Thus, an electric field can separate protein and carbohydrate rich fractions depending upon their types and magnitudes of charge. Like air classification, the main advantages of this method are that it does not use chemical reagents that render the concentrates unsafe for consumption, or that induce changes in functional character. This method is more energy efficient and effective than air classification because it effectively separates particles that are similar in size and density, but different in charge. The major limitation of this approach is that different components may exhibit similar charges under certain conditions, which reduces concentrate purity, and gravitational force may cause airborne particles [125].

Triboelectrostatic separation of legume flours pneumatically conveys the milled particles through tubes or fluidized/vibrating beds, thus imparting a positive or negative charge to the surface of the constituent protein and carbohydrate particles depending on their tribo-charging behavior and the contact medium. Upon contact charging, the oppositely charged particles are separated in a strong electric field [126]. The amount of charge gained on a particulate from triboelectric charging depends on factors such as surface conditions, area of contact, speed of rubbing, the materials involved, and humidity [123]. Electrostatic separation methods have been widely used in the mining and pharmaceutical industries, and the effectiveness of this approach is under investigation in the legume industry. For example, the development of optimization of triboelectric bio-separation using a single-stage separation of navy bean flour was successful [126]. Later, single- and multi-stage tribo-electrostatic bioseparation processes for dry fractionation of protein concentrate found that the two-stage approach resulted in a protein-rich fraction yield of $38 \%$ accounting for $60 \%$ of the total protein which was a significantly higher than that of the optimized single-stage triboelectrostatic separation [127]. Similarly, Jafari et al. [124] and Tabtabaei et al. [128] examined the physiochemical and functional properties of navy bean protein concentrated using triboelectrostatic separation. They found that electrostatically separated increased from $25.4 \%$ to $43.0 \%$ total protein yield of original navy bean flour, the protein fractions protein fractions exhibited superior solubility, superior emulsion stability, foam expansion and foam volume stability compared to the wet-fractionated navy bean protein isolate. This method has been extensively explored for fractionation of protein isolated from navy bean and other legumes, but there is limited information in the literature regarding the fractionation of protein from lentil flour using triboelectrostatic processes. However, the variation in turbocharging behavior of proteins and carbohydrates of flour extends its scope to protein isolation of lentil flours.

\section{Bioactive Peptides}

Food proteins not only provide dietary amino acids but also supply health benefits because of the presence of bioactive peptides, short fragments of 2-20 amino acid residues that are encrypted and inactive within the sequence of the precursor protein. Bioactive peptides play an important role in human health, being released during digestion or food processing (enzymatic hydrolysis, cooking, germination, fermentation, and ripening of foods), then absorbed in the intestine and transported to target tissues where they exert specific physiological effects [129].

Proteins from pulses are considered a good source of bioactive peptides. As an example, lentil convicilin was investigated as a source of bioactive peptides using the predictive tools in the BIOPEP database (http://www.uwm.edu.pl/biochemia, see Supplementary Table S1). This storage protein contains a total of 126 peptides encrypted in the amino acid sequence. The following array of biological effects was reported: (i) inhibition of angiotensin I converting enzyme (ACE), dipeptidyl aminopeptidase III and IV, calmodulin-dependent nucleotide phosphodiesterase (CaNPDE), and renin; (ii) stimulation of the release of vasoactive substances and the uptake of glucose; (iii) antioxidant 
activity, and (iv) regulation of secretion of gastric mucosa. This fact encourages more research studies exploring the biotechnological production of bioactive peptides from lentil proteins for functional food or nutraceutical applications.

A few studies are reported with the aim of ensuring efficient peptide release from lentil proteins. Critical processing parameters, such as $\mathrm{pH}$, temperature and time require optimization, and the enzymes or microorganisms used for peptide release require evaluation for efficacy, reproducibility and stability. Enzymatic hydrolysis of lentil proteins has been performed using a wide number of proteolytic enzymes including Savinase, Alcalase, Protamex, Neutrase, Flavourzyme, bromelain, and papain $[130,131]$. Savinase ${ }^{\circledR} 16 \mathrm{~L}$ was reportedly the most effective enzyme to produce bioactive peptides from cultivated lentil concentrates [130].

Bioactive peptides derived from lentil proteins reportedly exhibit antihypertensive, antioxidant, and antifungal activities. Table 6 summarizes the in vitro effect of protein hydrolysates and bioactive peptides produced during gastrointestinal digestion, enzymatic hydrolysis, germination and fermentation of different lentil-based raw materials. Most studies performed to date have shown that enzymatic hydrolysis of lentil proteins by food grade commercial proteases (savinase, papain, alcalase, flavourzyme, and bromelain), digestive enzymes (pepsin, trypsin, $\alpha$-chymotrypsin, pancreatin) or germination of lentil seeds $\left(30-40{ }^{\circ} \mathrm{C}\right.$ for 5 days) produce peptides with the ability to inhibit angiotensin I converting enzyme (ACE, EC. 3.4.15.1) (see Table 6). ACE is a carboxypeptidase involved in the cleavage of angiotensin I into angiotensin II, a vasoactive peptide that binds with receptors on the vascular wall to cause vasoconstriction, therefore, inhibition of ACE may reduce systolic and diastolic blood pressure [132].

Cultivated lentil proteins treated with Savinase ${ }^{\circledR}$ produce multifunctional peptides with dual antioxidant and ACE inhibitory activities [133]. Three peptides were identified to have the highest potencies for inhibiting ACE and delay oxidation of proteins in the presence of oxygen radicals in vitro (LLSGTQNQPSFLSGF, NSLTLPILRYL, TLEPNSVFLPVLLH). The gastrointestinal digestion of these peptides greatly improved their dual biological activity, indicating that smaller peptide fragments with higher biological potency are produced at the gastrointestinal level. The antioxidant/antihypertensive activity of lentil peptides was linked to the primary structure of the C-terminal heptapeptide [133]. In particular, the ACE inhibition relies on the formation of hydrogen bonds between C-terminal residues of peptides and residues of the ACE catalytic site. The ability of these peptides to inhibit ACE is consistent with earlier studies showing that hydrophobic or aromatic residues or proline residue at the C-terminus positively contribute to the improvement of ACE inhibitory potency [134].

Lentil proteins are also sources of antifungal peptides with potential application as ingredients in the bakery industry. Recently, Rizzello et al. [135] produced a hydrolysate from a legume flour blend consisting of lentil, pea and faba bean by the combination of fermentation with Lactobacillus plantarum 1A7 and enzymatic hydrolysis with Veron. Among the antifungal compounds of the hydrolysate, four were identified as antifungal peptides derived from lentil lectin. These were purified to confirm their capacity to inhibit the development of Penicillium roqueforti conidia at a minimum inhibitory concentration of 7-9 mg/mL. Similarly, Wang and $\mathrm{Ng}$ [136] isolated a natural antifungal peptide from a red lentil protein extract by chromatographic fractionation. It was able to inhibit $50 \%$ of the mycelial growth of Mycosphaerella arachidicola at a concentration of $36 \mu \mathrm{M}$.

Although bioactive peptides have been identified and isolated from lentil for potential use in functional food and nutraceutical applications, none are currently available in the market for human use. The principal obstacle to the regulatory approval of health claims is the lack of in vivo studies supporting the health and safety claims of bioactive peptides [137]. To overcome these challenges, future research should focus more on generating data on the safety, efficacy, mechanisms of action, interactions of bioactive peptides with other drugs, absorption, distribution, metabolism, and excretion of bioactive peptides in clinical trials. 
Table 6. In vitro biological activity of cultivated lentil protein hydrolysates and peptides.

\begin{tabular}{|c|c|c|c|c|c|}
\hline Biological Activity & Raw Material & Processing Conditions & Peptide Sequence & Effect Observed & Reference \\
\hline \multirow{3}{*}{$\begin{array}{l}\text { Antioxidant and } \\
\text { antihypertensive }\end{array}$} & \multirow{3}{*}{ Protein concentrate } & \multirow{3}{*}{$\begin{array}{l}\text { Enzymatic hydrolysis with Savinase } 16 \mathrm{~L}(0.1 \\
\left.\mathrm{U} / \mathrm{mg} \text { protein, } \mathrm{pH} 8,40^{\circ} \mathrm{C}, 2 \mathrm{~h}\right)\end{array}$} & LLSGTQNQPSFLSGF $^{1}$ & $\begin{array}{c}\text { ACE }^{2} \text { inhibition: } \mathrm{IC}_{50}{ }^{3}=120 \mu \mathrm{M} \\
\text { ORAC }^{4}: 0.013 \mu \mathrm{mol} \text { Trolox } \\
\text { eq. } / \mu \mathrm{mol}\end{array}$ & \multirow{3}{*}{$\begin{array}{l}\text { Garcia-Mora et al. } \\
{[133]}\end{array}$} \\
\hline & & & NSLTLPILRYL & $\begin{array}{c}\text { ACE inhibition: } \mathrm{IC}_{50}=77.14 \mu \mathrm{M} \\
\text { ORAC: } 1.432 \mu \mathrm{mol} \text { Trolox } \\
\text { eq. } / \mu \mathrm{mol}\end{array}$ & \\
\hline & & & TLEPNSVFLPVLLH & $\begin{array}{c}\text { ACE inhibition: } \mathrm{IC}_{50}=117.81 \mu \mathrm{M} \\
\text { ORAC: } 0.139 \mu \mathrm{mol} \text { Trolox } \\
\text { eq. } / \mu \mathrm{mol}\end{array}$ & \\
\hline Antihypertensive & Sprouts & $\begin{array}{c}\text { Germination ( } 30-40^{\circ} \mathrm{C} \text { for } 5 \text { days, } 98 \% \\
\text { humidity) }\end{array}$ & Unknown & $\begin{array}{c}\text { ACE inhibition: } \mathrm{IC}_{50}=0.044 \text { and } \\
0.034 \mathrm{mg} / \mathrm{mL}\end{array}$ & $\begin{array}{l}\text { Mamilla and Mishra } \\
{[138]}\end{array}$ \\
\hline \multirow{4}{*}{ Antifungal } & \multirow{4}{*}{ Flour } & \multirow{4}{*}{$\begin{array}{l}\text { Fermentation with Lactobacillus plantarum }(7 \mathrm{log} \\
\mathrm{cfu} / \mathrm{g}) \text { and enzymatic hydrolysis with Veron PS } \\
\left(\mathrm{E} / \mathrm{S}^{5} \text { of } 1 / 400,30^{\circ} \mathrm{C}, 24 \mathrm{~h}\right)\end{array}$} & HIGIDVNSIK & \multirow{4}{*}{$\begin{array}{l}\text { Inhibition of germination of } \\
\text { Penicillium roqueforti DPPMAF1 } \\
\text { conidia: } \text { MIC }^{6}=7-9 \mathrm{mg} / \mathrm{mL}\end{array}$} & \multirow{4}{*}{ Rizzello et al. [135] } \\
\hline & & & NLIFQGDGYTTK & & \\
\hline & & & FSPDQQNLIFQGDGYTTK & & \\
\hline & & & HIGIDVNSIK & & \\
\hline Antihypertensive & Protein isolate & $\begin{array}{l}\text { Enzymatic hydrolysis with pepsin (E/S of 1/100, } \\
\left.\qquad \mathrm{pH} 2,37^{\circ} \mathrm{C} \text { for } 18 \mathrm{~h}\right)\end{array}$ & Unknown & ACE inhibition: $\mathrm{IC}_{50}=606 \mu \mathrm{g} / \mathrm{mL}$ & Boschin et al. [139] \\
\hline \multirow{3}{*}{ Antihypertensive } & \multirow{3}{*}{ Protein isolate } & \multirow{3}{*}{$\begin{array}{l}\text { Pepsin }\left(250 \mathrm{U} / \mathrm{mg}, \mathrm{pH} 2,37^{\circ} \mathrm{C}, 2 \mathrm{~h}\right) \text { and } \\
\text { pancreatin }\left(0.7 \%, \mathrm{pH} 7,37^{\circ} \mathrm{C}, 1 \mathrm{~h}\right)\end{array}$} & KLRT & ACE inhibition: & \multirow{3}{*}{$\begin{array}{l}\text { Jakubczyk and } \\
\text { Baraniak [140] }\end{array}$} \\
\hline & & & TLHGMV & $\begin{array}{l}\mathrm{IC}_{50}=0.13-0.02 \mathrm{mg} / \mathrm{mL} \text { for } \\
\text { different peptide fractions }\end{array}$ & \\
\hline & & & VNRLM & & \\
\hline \multirow{8}{*}{ Antihypertensive } & \multirow{4}{*}{$\begin{array}{l}\text { Red protein } \\
\text { concentrates }\end{array}$} & $\begin{array}{l}\text { Pepsin }\left(\mathrm{E} / \mathrm{S} \text { of } 1 / 250 \text {, for } 2 \mathrm{~h}, \mathrm{pH} 2,37^{\circ} \mathrm{C}\right)+ \\
\text { Trypsin and } \alpha \text {-chymotrypsin }(\mathrm{E} / \mathrm{S} \text { of } 1 / 250 \text { for } \\
\left.\text { each enzyme, } 2.5 \mathrm{~h}, \mathrm{pH} 6.5,37^{\circ} \mathrm{C}\right)\end{array}$ & Unknown & $\begin{array}{l}\text { ACE inhibition: } \\
\mathrm{IC}_{50}=0.090 \mathrm{mg} / \mathrm{mL}\end{array}$ & \multirow{8}{*}{$\begin{array}{l}\text { Barbana and Boye } \\
\text { [131] }\end{array}$} \\
\hline & & Papain (E/S of $\left.1 / 25, \mathrm{pH} 6.5,4 \mathrm{~h}, 40^{\circ} \mathrm{C}\right)$ & Unknown & $\mathrm{IC}_{50}=0.086 \mathrm{mg} / \mathrm{mL}$ & \\
\hline & & $\begin{array}{l}\text { Alcalase }\left(1 / 8 \text { for } \mathrm{E} / \mathrm{S} \text { ratio, } \mathrm{pH} 7,1 \mathrm{~h}, 50^{\circ} \mathrm{C}\right)+ \\
\text { Flavourzyme }\left(\mathrm{E} / \mathrm{S} \text { of } 1 / 10, \mathrm{pH} 8,1.5 \mathrm{~h} \text { at } 50^{\circ} \mathrm{C}\right)\end{array}$ & Unknown & $\mathrm{IC}_{50}=0.154 \mathrm{mg} / \mathrm{mL}$ & \\
\hline & & Bromelain $\left(\mathrm{E} / \mathrm{S}\right.$ of $\left.1 / 4, \mathrm{pH} 8,8 \mathrm{~h}, 40^{\circ} \mathrm{C}\right)$ & Unknown & $\mathrm{IC}_{50}=0.190 \mathrm{mg} / \mathrm{mL}$ & \\
\hline & \multirow{4}{*}{$\begin{array}{l}\text { Green protein } \\
\text { concentrates }\end{array}$} & $\begin{array}{l}\text { Pepsin (pepsin }\left(\mathrm{E} / \mathrm{S} \text { of } 1 / 250, \text { for } 2 \mathrm{~h}, \mathrm{pH} 2,37^{\circ} \mathrm{C}\right) \\
+ \text { Trypsin and } \alpha \text {-chymotrypsin }(\mathrm{E} / \mathrm{S} \text { of } 1 / 250 \text { for } \\
\left.\text { each enzyme, } 2.5 \mathrm{~h}, \mathrm{pH} 6.5,37^{\circ} \mathrm{C}\right)\end{array}$ & Unknown & $\begin{array}{c}\text { ACE inhibition: } \\
\mathrm{IC}_{50}=0.053 \mathrm{mg} / \mathrm{mL}\end{array}$ & \\
\hline & & Papain $\left(\mathrm{E} / \mathrm{S}\right.$ of $\left.1 / 25, \mathrm{pH} 6.5,4 \mathrm{~h}, 40^{\circ} \mathrm{C}\right)$ & Unknown & $\mathrm{IC}_{50}=0.080 \mathrm{mg} / \mathrm{mL}$ & \\
\hline & & $\begin{array}{c}\text { Alcalase }\left(1 / 8 \text { for } \mathrm{E} / \mathrm{S} \text { ratio, } \mathrm{pH} 7,1 \mathrm{~h}, 50^{\circ} \mathrm{C}\right)+ \\
\text { Flavourzyme }\left(\mathrm{E} / \mathrm{S} \text { of } 1 / 10, \mathrm{pH} 8,1.5 \text { h at } 50^{\circ} \mathrm{C}\right)\end{array}$ & Unknown & $\mathrm{IC}_{50}=0.152 \mathrm{mg} / \mathrm{mL}$ & \\
\hline & & Bromelain $\left(\mathrm{E} / \mathrm{S}\right.$ of $\left.1 / 4, \mathrm{pH} 8,8 \mathrm{~h}, 40^{\circ} \mathrm{C}\right)$ & Unknown & $\mathrm{IC}_{50}=0.174 \mathrm{mg} / \mathrm{mL}$ & \\
\hline
\end{tabular}


Table 6. Cont.

\begin{tabular}{|c|c|c|c|c|c|}
\hline Biological Activity & Raw Material & Processing Conditions & Peptide Sequence & Effect Observed & Reference \\
\hline \multirow[t]{2}{*}{ Antihypertensive } & \multirow[t]{2}{*}{ Red protein isolates } & \multirow{2}{*}{$\begin{array}{l}\text { Pepsin (E/S of 4/10, pH } 2,37^{\circ} \mathrm{C}, 2 \mathrm{~h} \text { ) and } \\
\text { pancreatin (E/S of } 0.5 / 10, \mathrm{pH} 7,37^{\circ} \mathrm{C}, 2 \mathrm{~h} \text { ) }\end{array}$} & \multirow[t]{2}{*}{ Unknown } & $\begin{array}{c}\text { ACE inhibition: } \\
\mathrm{IC}_{50}=0.008-0.33 \mathrm{mg} / \mathrm{mL} \text { in } \\
\text { gastric phase }\end{array}$ & \multirow{2}{*}{$\begin{array}{l}\text { Akıllıoğlu and } \\
\text { Karakaya [141] }\end{array}$} \\
\hline & & & & $\begin{aligned} & \mathrm{IC}_{50}=0.26-0.89 \mathrm{mg} / \mathrm{mL} \text { in } \\
& \text { intestinal phase }\end{aligned}$ & \\
\hline Antifungal & Red lentil extract & Chromatographic fractionation & TETNSFSITKFSPDGNKLIFQGDGYTTKGK & $\begin{array}{l}\text { Inhibition of mycelial growth in } \\
\text { Mycosphaerella arachidicola: } \mathrm{IC}_{50}= \\
\qquad 36 \mathrm{M}\end{array}$ & Wang and Ng [136] \\
\hline
\end{tabular}




\section{Food Applications of Lentil Proteins}

Lentil protein ingredients represent a viable alternative to proteins from animal-derived sources and soybean, especially since the food industry aims to diversify their formulations because of cultural, religious or ethical dietary restrictions, growing populations, availability, and cost reduction. Although commonly sold as flours, lentil protein ingredients can also be further fractionated into higher protein enriched flours ( $<60 \%$ protein), concentrates $(60 \%-85 \%$ protein) or isolates ( $>85 \%$ protein). Enriched flours and dry concentrates are usually produced by air classification methods [142], whereas concentrates/isolates are produced using wet extraction processes, such as by alkaline extraction followed by isoelectric precipitation [109]. These fractions are known to have good nutritional and functional value. In terms of functionality, the method and conditions used to produce the ingredients can have a big impact on their functionality within food applications.

\subsection{Functionality}

The majority of published studies have focused on the solubility and emulsifying properties of lentil proteins. Solubility of lentil proteins relates to the balance between protein-solvent and protein-protein interactions. Ladjal-Ettoumi et al. [143] reported a typical u-shaped $\mathrm{pH}$-dependent solubility profile that was comparable to pea and chickpea proteins, where proteins assume a high surface charge away from their isoelectric point (net charge of $0 \mathrm{mV}, \mathrm{pH} 4.5$ ) to promote more protein-solvent interactions (e.g., $+30 \mathrm{mV}$ at $\mathrm{pH} \mathrm{2}$, and $-40 \mathrm{mV}$ at $\mathrm{pH}$ 8). Minimum solubility was found near the isoelectric point $(\sim 15 \%)$, and higher solubility at $\mathrm{pH} 2$ and $8(\sim 65 \%)$. Can Karaca et al. [144] found lentil protein isolates at pH 7 to have high solubility (91\%) when produced either from alkaline extraction-isoelectric precipitation or by salt extraction. Boye et al. [145] reported lentil protein concentrates produced by alkaline extraction-ultrafiltration showed greater solubility than those produced by alkaline extraction-isoelectric precipitation, with both showing the u-shaped pH-dependent profile.

Lentil protein isolates have demonstrated excellent emulsifying properties. During emulsion formation, proteins migrate to the oil-water interface and then rearrange to orient hydrophobic groups towards the oil phase and hydrophilic groups towards the water phase, lowering interfacial tension. Aggregation of absorbed proteins then creates a viscoelastic interfacial film to stabilize oil droplets from coalescence and gravitational separation. Ladjal-Ettoumi et al. [143] and Chang et al. [146] reported lentil protein-stabilized emulsions were most stable at $\mathrm{pH}$ levels away from their isoelectric point. Can Karaca et al. [144] indicated protein isolates prepared by alkaline extraction-isoelectric precipitation to have greater emulsion forming properties and stability than if salt extraction methods were used to prepare the isolates. Primozic et al. [147] examined the stabilizing effects of high-pressure homogenized lentil protein isolates relative to unmodified isolates. The authors found that homogenization acted to reduce the particle size, hydrophobicity, and interfacial storage moduli of the lentil proteins relative to unmodified proteins, but had no effect on their interfacial tension. Overall, modified lentil proteins showed better physical stability for prepared emulsions than unmodified proteins. Gumus et al. [148] showed that lentil protein-stabilized emulsions were also effective at inhibiting oxidative reactions within fish oil-in-water emulsions.

Water holding and fat/oil absorption capacities relates to the amount of water or oil that a gram of protein material can hold, and to the surface properties (hydrophilic vs. hydrophobic groups), protein/aggregate conformation and solvent conditions used. Aryee and Boye [149] reported both water holding and fat absorption capacities were improved with wet extraction (i.e., isolate), followed by cooked flour and then raw flour. Boye et al. [145] indicated that red lentil protein concentrates produced by alkaline extraction-ultrafiltration exhibited greater water holding and fat absorption capacities than concentrates produced by alkaline extraction-isoelectric precipitation. Water holding was similar to that of yellow pea, and greater than that of chickpea. Fat absorption capacity of red lentil protein concentrates (produced from alkaline extraction-ultrafiltration) was much greater than that of other pulses. In the case of foaming, proteins migrate to the air-water interface, re-align and 
aggregate similar as in emulsions, to form a viscoelastic lamella that entraps gas bubbles [39]. Toews and Wang [150] reported that lentil protein concentrate produced the most stable foams and had the highest foaming capacity in comparison to pea, navy bean and chickpea. Lately, investigation of the foaming properties of the pulse cooking water (known as aquafaba) is gaining some interest as an egg replacer [151]. This highlights an opportunity for food technologists to apply lentil proteins in food applications.

\subsection{Challenges}

Like other pulses, lentil protein ingredients also have unwanted flavour compounds that limit their widespread use. Numerous flavour reduction strategies are available to reduce these compounds in pulses. For instance, Chang et al. [152] used various organic solvent (acetone, ethanol, and isopropanol) treatments to reduce flavour compounds found in lentil protein isolates, however, this resulted in negative effects on protein functionality. Shariati-Levari et al. [153] used infrared heating to reduce flavour compounds in lentils, and Ma et al. [154] reported pre-cooking (roasting and cooking) significantly reduced flavour compounds in green lentils.

\subsection{Applications}

Lentil protein concentrates have been used to replace eggs in production of protein-enriched doughnuts [155], angel food cake, and muffins [156]. Lentil flour was used to make gluten-free crackers [157], lentil flour with transglutaminase has been used as a binding agent to make protein-enriched restructured beef steaks or beef patties [158,159], and lentil protein isolates have been used as an emulsifier to produce salad dressings [160]. Lentil protein isolates have also been applied as stabilizers for nano emulsion systems $[147,161]$, as encapsulation agents for delivery of omega-3 rich oils [162,163], and in combination with zein, as anti-microbial films [164], and used to produce nanofibers [165]. Keeping in mind the many technological functions of lentil proteins, niches are emerging for their inclusion in functional foods, in nutraceuticals, or even in cosmetics.

\section{Conclusions}

Lentil is the most rapidly expanding pulse crop for direct human consumption, and has potential for greater impact as a desirable protein source for food applications. Improvements in lentil protein quality, amino acid composition, and processing fractions will enhance the nutritional quality of this rapidly expanding pulse crop. Genetic strategies focused on increasing the concentration of limiting amino acids are required in lentil. The potential of lentil wild species in breeding programs by introgression of favourable genes for protein improvement may have potential as a long-term breeding strategy.

Supplementary Materials: The following are available online at http://www.mdpi.com/2304-8158/8/9/391/s1, Table S1: List of peptides with bioactive potential encrypted in lentil (Lens culinaris Medik.) convicilin (see http://www.uwm.edu.pl/biochemia).

Author Contributions: Conceptualization, H.K. and A.V.; writing-original draft preparation, H.K.; writing—review and editing, H.K., M.S., M.N., C.M-V., J.F., and A.V.

Funding: This study received support from the Natural Sciences and Engineering Research Council of Canada (NSERC) Industrial Research Chair Program, from the Saskatchewan Pulse Growers (SPG), and from Institute of Food Science, Technology and Nutrition - Spanish National Research Council (ICTAN-CSIC, Madrid, Spain, funded by project AGL2013-43247-R from AEI/FEDER UE) and from the Strategic Research Chair Program of the Saskatchewan Ministry of Agriculture.

Conflicts of Interest: The authors declare no conflict of interest.

\section{References}

1. Krishnan, H.B.; Coe, E.B., Jr. Seed storage proteins. In Encyclopedia of Genetics; Science Direct: Amsterdam, The Netherlands, 2001; pp. 1782-1787. 
2. Nosworthy, M.G.; Neufeld, J.; Frohlich, P.; Young, G.; Malcolmson, L.; House, J.D. Determination of the protein quality of cooked Canadian pulses. Food Sci. Nutr. 2017, 5, 896-903. [CrossRef] [PubMed]

3. Vandenberg, A.; Slinkard, A.E. Genetics of seed coat color and pattern in lentil. J. Hered. 1990, 81, 484-488. [CrossRef]

4. Vandenberg, A. Lentil: Improvement in developing countries. In The Lentil: Botany, Production and Uses; Erskine, W., Muehlbauer, F.J., Sarker, A., Sharma, B., Eds.; CAB International: Oxford, UK, 2009; pp. 391-424.

5. Muehlbauer, F.J. Lentil: improvement in developing countries. In The Lentil: Botany, Production and Uses; Erskine, W., Muehlbauer, F.J., Sarker, A., Sharma, B., Eds.; CAB International: Oxford, UK, 2009; pp. 137-154.

6. Khazaei, H.; Caron, C.T.; Podder, R.; Kundu, S.S.; Diapari, M.; Vandenberg, A.; Bett, K.E. Marker-trait association analysis of iron and zinc concentrations in lentils (Lens culinaris Medik.) seeds. Plant Genome. 2017, 10, 1-8. [CrossRef] [PubMed]

7. Grela, E.R.; Kiczorowska, B.; Samolińska, W.; Matras, J.; Kiczorowski, P.; Rybiński, W.; Hanczakowska, E. Chemical composition of leguminous: Part I-Content of basic nutrients, amino acids, phytochemical compounds and antioxidant activity. Eur. Food Res. Technol. 2017, 243, 1385-1395. [CrossRef]

8. Tahir, M.; Lindeboom, N.; Båga, M.; Vandenberg, A.; Chibbar, R.N. Composition and correlation between major seed constituents in selected lentil (Lens culinaris Medik). Can. J. Plant Sci. 2011, 91, 825-835. [CrossRef]

9. Food and Agriculture Organization of the United Nations. FAOSTAT. Available online: http://faostat.fao.org (accessed on 2 September 2019).

10. Semba, R.D. The rise and fall of protein malnutrition in global health. Ann. Nutr. Metab. 2016, 69, 79-88. [CrossRef]

11. Arsenault, J.E.; Brown, K.H. Effects of protein or amino-acid supplementation on the physical growth of young children in low-income countries. Nutr. Rev. 2017, 75, 699-717. [CrossRef]

12. Barulina, H. Lentils of the U.S.S.R. and of other countries: A botanic-agronomical monograph. In Bulletin of Applied Botany, of Genetics and Plant-Breeding; Leningrad Vsesoiuznaia akademiia sel'sko khoziaistvennyk im: Leningrad (St. Petersburg), Russia, 1930; Suppl. S40, pp. 1-319.

13. Hawtin, G.C.; Rachie, K.O.; Green, J.M. Breeding strategy for the nutritional improvement of pulses. In Nutritional Standards and Methods of Evaluation for Food Legume Breeders; Hulse, J.H., Rachie, K.O., Billingsley, L.W., Eds.; IDRC: Ottawa, ON, Canada, 1977; pp. 43-51.

14. Hamdi, A.; Erskine, W.; Gates, P. Relationships among economic characters in lentil. Euphytica 1991, 57, 109-116. [CrossRef]

15. Kumar, J.; Singh, J.; Kanaujia, R.; Gupta, S. Protein content in wild and cultivated taxa of lentil (Lens culinaris ssp. culinaris Medikus). Indian J. Genet. Plant Breed. 2016, 76, 631-634.

16. Erskine, W.; Williams, P.C.; Nakkoul, H. Genetic and environmental variation in the seed size, protein, yield, and cooking quality of lentils. Field Crops Res. 1985, 12, 153-161. [CrossRef]

17. Stoddard, F.L.; Marshall, D.R.; Ali, S.M. Variability in grain protein concentration of peas and lentils grown in Australia. Aust. J. Agric. Res. 1993, 44, 1415-1419. [CrossRef]

18. Hedley, C.L. Carbohydrate in Grain Legume Seeds; CAB International: Wallingford, UK, 2001; pp. 1-11.

19. Wang, N.; Daun, J.K. Effects of variety and crude protein content on nutrients and anti-nutrients in lentils (Lens culinaris). Food Chem. 2006, 95, 493-502. [CrossRef]

20. Karaköy, T.; Erdem, H.; Baloch, F.S.; Toklu, F.; Eker, S.; Kilian, B.; Özkan, H. Diversity of macro-and micronutrients in the seeds of lentil landraces. Sci. World J. 2012, 2012, 1-9. [CrossRef] [PubMed]

21. Zaccardelli, M.; Lupo, F.; Piergiovanni, A.R.; Laghetti, G.; Sonnante, G.; Daminati, M.G.; Sparvoli, F.; Lioi, L. Characterization of Italian lentil (Lens culinaris Medik.) germplasm by agronomic traits, biochemical and molecular markers. Genet. Resour. Crop Evol. 2012, 59, 727-738. [CrossRef]

22. Alghamdi, S.S.; Khan, A.M.; Ammar, M.H.; El-Harty, E.H.; Migdadi, H.M.; Abd El-Khalik, S.M.; Al-Shameri, A.M.; Javed, M.M.; Al-Faifi, S.A. Phenological, nutritional and molecular diversity assessment among 35 introduced lentil (Lens culinaris Medik.) genotypes grown in Saudi Arabia. Int. J. Mol. Sci. 2014, 15, 277-295. [CrossRef]

23. Heuzé, V.; Tran, G.; Sauvant, D.; Bastianelli, D.; Lebas, F. Lentil (Lens culinaris). Feedipedia, a programme by INRA, CIRAD, AFZ and FAO. 2015. Available online: https://www.feedipedia.org/node/284 (accessed on 2 September 2019).

24. Shewry, P.R. Seed storage proteins: structures and biosynthesis. Plant Cell Online 1995, 7, 945-956. 
25. Sales, M.P.; Gerhardt, I.S.; Grossi-de-Sá, F.; Xavier-Filho, J. Do legume storage proteins play a role in Defending seeds against bruchids? Plant Physiol. 2000, 124, 512-522. [CrossRef]

26. Cândido Ede, S.; Pinto, M.F.; Pelegrini, P.B.; Lima, T.B.; Silva, O.N.; Pogue, R.; Grossi-de-Sá, M.F.; Franco, O.L. Plant storage proteins with antimicrobial activity: Novel insights into plant defense mechanisms. FASEB J. 2011, 25, 3290-3305. [CrossRef]

27. Osborne, T.B.; Campbell, G.F. Proteins of lentils. J. Am. Chem. Soc. 1898, 20, 362-375. [CrossRef]

28. Danielson, C.E. An electrophoretic investigation of vicilin and legumin from seeds of peas. Acta Chem. Scand. 1950, 4, 762-771. [CrossRef]

29. Siddiqi, S.H. Chromatography on DEAE-cellulose and electrophoresis in polyacrylamide gel of protein fractions from lentil seeds. Pak. J. Sci. Ind. Res. 1982, 25, 167-169.

30. Bhatty, R.S. Composition and quality of lentil (Lens culinaris): A review. Can. Inst. Food Sci. Technol. J. 1988, 21, 144-160. [CrossRef]

31. Scippa, G.S.; Rocco, M.; Ialicicco, M.; Trupiano, D.; Viscosi, V.; Di Michele, M.; Arena, S.; Chiatante, D.; Scaloni, A. The proteome of lentil (Lens culinaris Medik.) seeds: Discriminating between landraces. Electrophoresis 2010, 31, 497-506. [CrossRef] [PubMed]

32. Neves, V.A.; Lourenco, E.J. Isolation and in vitro hydrolysis of globulin G1 from lentils (Lens culinaris Medik). J. Food Biochem. 1995, 19, 109-120. [CrossRef]

33. Bourgeois, M.; Jacquin, F.; Savois, V.; Sommerer, N.; Labas, V.; Henry, C.; Burstin, J. Dissecting the proteome of pea mature seeds reveals the phenotypic plasticity of seed protein composition. Proteomics 2009, 9, $254-271$. [CrossRef] [PubMed]

34. Saint-Clair, P.M. Responses of Lens Esculenta Moench to Controlled Environmental Factors. Ph.D. Thesis, Committee of Agriculture, Wangeningen University, Wangeningen, The Netherlans, 1972; pp. 72-77.

35. Bhatty, R.S.; Slinkard, A.E.; Sosulski, F.W. Chemical composition and protein characteristics of lentils. Can. J. Plant Sci. 1976, 56, 787-794. [CrossRef]

36. Bhatty, R.S. In vitro hydrolysis of pea, faba bean and lentil meals and isolated protein fractions by pepsin and trypsin. Can. Inst. Food Sci. Technol. J. 1988, 21, 66-71. [CrossRef]

37. Sulieman, M.A.; Amro, B.H.; Gamaa, A.O.; Mohamed, M.E.T.; Elhadi, A.I.E.K.; Abdullahi, H.E.T.; Elfadil, E.B. Changes in total protein digestibility, fractions content and structure during cooking of lentil cultivars. Pak. J. Nutr. 2008, 7, 801-805.

38. Boye, J.I.; Aksay, A.; Roufik, S.; Ribereau, S.; Mondor, M.; Farnworth, E.; Rajamohamed, S.H. Comparison of the functional properties of pea, chickpea and lentil protein concentrates processed using ultrafiltration and isoelectric precipitation techniques. Food Res. Int. 2010, 43, 537-546. [CrossRef]

39. Jarpa-Parra, M. Lentil protein: A review of functional properties and food application. An overview of lentil protein functionality. Int. J. Food Sci. Technol. 2018, 53, 892-903. [CrossRef]

40. World Health Organization/Food and Agriculture-Organization of the United Nations/United Nations University. Protein and Amino Acid Requirements in Human Nutrition; Report of a Joint WHO/FAO/UNU Expert Consultation; WHO Technical Report Series 935; World Health Organization: Geneva, Switzerland, 2007.

41. Kahn, N.A.; Baker, B.E. The amino-acid composition of some Pakistani pulses. J. Sci. Food Agric. 1957, 8 , 301-305. [CrossRef]

42. Chatterjee, S.R.; Abrol, Y.P. Amino acid composition of new varieties of cereals and pulses and nutritional potential of cereal-pulse combinations. J. Food Sci. Technol. 1975, 12, 221-227.

43. Sosulski, F.W. Legume protein concentration by air classification. In Developments in Food Proteins-2; Hudson, B.J.F., Ed.; Applied Science Publishers: Essex, UK, 1983.

44. Bhatty, R.S.; Christison, G.I. Composition and nutritional quality of pea (Pisum sativum L.), faba bean (Vicia faba L. spp. minor) and lentil (lens culinaris Medik) meals, protein concentrates and isolates. Qual. Plant Plant Foods Hum. Nutr. 1984, 34, 41-51. [CrossRef]

45. Shekib, L.A.H.; Zoueil, M.E.; Youssef, M.M.; Mohamed, M.S. Amino acid composition and in vitro digestibility of lentil and rice proteins and their mixture (Koshary). Food Chem. 1986, 20, 61-67. [CrossRef]

46. Pirman, T.; Stibilj, V.; Stekar, J.M.A.; Combe, E. Amino acid composition of beans and lentil. Zb. Bioteh. Fak. Univ. Ljubl. Kmet. Zooteh. 2001, 78, 57-68.

47. Porres, J.M.; Urbano, G.; Fernández-Fígares, I.; Prieto, C.; Pérez, L.; Aguilera, J.F. Digestive utilisation of protein and amino acids from raw and heated lentils by growing rats. J. Sci. Food Agric. 2002, 82, 1740-1747. [CrossRef] 
48. Zia-Ul-Haq, M.; Ahmad, S.; Shad, M.A.; Iqbal, S.; Qayum, M.; Ahmad, A.; Luthria, D.L.; Amarowicz, R. Compositional studies of lentil (Lens culinaris Medik.) cultivars commonly grown in Pakistan. Pak. J. Bot. 2011, 43, 1563-1567.

49. Kaldy, N.S.; Kasting, R. Amino acid composition and protein quality of eight faba bean cultivars. Can. J. Plant Sci. 1974, 54, 869-871. [CrossRef]

50. Lisiewska, Z.; Kmiecik, W.; Słupski, J. Content of amino acids in raw and frozen broad beans (Vicia faba var. major) seeds at milk maturity stage, depending on the processing method. Food Chem. 2007, 105, 1468-1473. [CrossRef]

51. Schumacher, H.; Paulsen, H.M.; Gau, A.E.; Link, W.; Jürgens, H.U.; Sass, O.; Dieterich, R. Seed protein amino acid composition of important local grain Lupinus angustifolius L., Lupinus luteus L., Pisum sativum L. and Vicia faba L. Plant Breed. 2011, 130, 156-164. [CrossRef]

52. Leterme, P.; Monmart, T.; Baudart, E. Amino acid composition of pea (Pisum sativum) proteins and protein profile of pea flour. J. Sci. Food Agric. 1990, 53, 107-110. [CrossRef]

53. Pownall, T.L.; Udenigwe, C.C.; Aluko, R.E. Amino acid composition and antioxidant properties of pea seed (Pisum sativum L.) enzymatic protein hydrolysate fractions. J. Agric. Food Chem. 2010, 58, 4712-4718. [CrossRef] [PubMed]

54. Kuiken, K.; Lyman, C.M.; Bradford, M.; Trant, M.; Dieterich, S. Essential amino acid composition of soy bean meals prepared from twenty strains of soy beans. J. Biol. Chem. 1949, 177, 29-36. [PubMed]

55. Tkachuk, H.; Irvine, G.N. Amino acid composition of cereals and oilseed meals. Cereal Chem. 1969, 16, 206-218.

56. Cho, C.Y.; Bayley, H.S. Evaluations of rapeseed and soybean meals as protein sources for swine: Apparent digestibilities of amino acids. Can. J. Anim. Sci. 1970, 50, 521-528. [CrossRef]

57. Cavins, J.F.; Kwolek, W.E.; Inglett, G.E.; Cowan, J.C. Amino acid analysis of soybean meal: Interlaboratory study. J. Asso. Off. Anal. Chem. 1972, 55, 686-691.

58. Wang, H.L.; Cavins, J.F. Yield and amino acid composition of fractions obtained during tofu production. Cereal Chem. 1989, 66, 359-361.

59. Zarkadas, C.G.; Gagnon, C.; Gleddie, S.; Khanizadeh, S.; Cober, E.R.; Guillemette, R.J.D. Assessment of the protein quality of fourteen soybean (Glycine max (L.) Merr.) cultivars using amino acid analysis and two-dimensional electrophoresis. Food Res. Int. 2007, 40, 129-146. [CrossRef]

60. Sotak-Peper, K.M.; González-Vega, J.C.; Stein, H.H. Amino acid digestibility in soybean meal sourced from different regions of the United States and fed to pigs. J. Anim. Sci. 2017, 95, 771-778. [CrossRef]

61. Wang, N.; Daun, J.K. The Chemical Composition and Nutritive Value of Canadian Pulses; Canadian Grain Commission Report; Canadian Commision: Winnipeg, MB, Canada, 2004; pp. 19-29.

62. Alajaji, S.A.; El-Adawy, T.A. Nutritional composition of chickpea (Cicer arietinum L.) as affected by microwave cooking and other traditional cooking methods. J. Food Comp. Anal. 2006, 19, 806-812. [CrossRef]

63. Wang, X.; Gao, W.; Zhang, J.; Zhang, H.; Li, J.; He, X.; Ma, H. Subunit, amino acid composition and in vitro digestibility of protein isolates from Chinese kabuli and desi chickpea (Cicer arietinum L.) cultivars. Food Res. Int. 2010, 43, 567-572. [CrossRef]

64. El-Beltagi, H.S.; El-Senousi, N.A.; Ali, Z.A.; Omran, A.A. The impact of using chickpea flour and dried carp fish powder on pizza quality. PLoS ONE 2017, 12, 1-15. [CrossRef] [PubMed]

65. Wu, W.; Williams, W.P.; Kunkel, M.E.; Acton, J.C.; Huang, Y.; Wardlaw, F.B.; Grimes, L.W. Amino acid availability and availability-corrected amino acid score of red kidney beans (Phaseolus vulgaris L.). J. Agric. Food Chem. 1996, 44, 1296-1301. [CrossRef]

66. Słupski, J. Effect of cooking and sterilisation on the composition of amino acids in immature seeds of flageolet bean (Phaseolus vulgaris L.) cultivars. Food Chem. 2010, 121, 1171-1176.

67. Djemel, N.; Guedon, D.; Lechevalier, A.; Salon, C.; Miquel, M.; Prosperi, J.M.; Rochat, C.; Boutin, J.P. Development and composition of the seeds of nine genotypes of the Medicago truncatula species complex. Plant Physiol. Biochem. 2005, 43, 557-566. [CrossRef] [PubMed]

68. Van Vliet, S.; Burd, N.A.; van Loon, L.J. The skeletal muscle anabolic response to plant-versus animal-based protein consumption. J. Nutr. 2015, 145, 1981-1991. [CrossRef]

69. Gorissen, S.H.M.; Crombag, J.J.R.; Senden, J.M.G.; Waterval, W.A.H.; Bierau, J.; Verdijk, L.B.; van Loon, L.J.C. Protein content and amino acid composition of commercially available plant-based protein isolates. Amino Acids 2018, 50, 1685-1695. [CrossRef] 
70. Rozan, P.; Kuo, Y.H.; Lambein, F. Amino acids in seeds and seedlings of the genus Lens. Phytochemistry 2001, 58, 281-289. [CrossRef]

71. Bell, E.A.; Lyddiard, J.R.A.; Malik, M.A.; Motevalli, M.; Nunn, P.B.; O’Brien, P.; Perera, K.P.W.C. X-ray single-crystal structure of 2(S),4(R)-4-hydroxyarginine from Lens culinaris seeds. Phytochemistry 1999, 50, 1201-1204. [CrossRef]

72. Sulser, H.; Sager, F. Identification of uncommon amino acids in the lentil seed (Lens culinaris Med.). Experientia 1976, 32, 422-423. [CrossRef]

73. Wong, M.M.L.; Gujaria-Verma, N.; Ramsay, L.; Yuan, H.Y.; Caron, C.; Diapari, M.; Vandenberg, A.; Bett, K.E. Classification and characterization of species within the genus Lens using genotyping-by-sequencing (GBS). PLoS ONE 2015, 10, e0122025. [CrossRef] [PubMed]

74. Bhatty, R.S. Protein subunits and amino acid composition of wild lentil. Phytochemistry 1986, 25, 641-644. [CrossRef]

75. Gatel, F. Protein-quality of legume seeds for non-ruminant animals-A literature-review. Anim. Feed Sci. Technol. 1994, 45, 317-348. [CrossRef]

76. Davis, K.R. Effect of processing on composition and Tetrahymena relative nutritive value on green and yellow peas, lentils and white pea beans. Cereal Chem. 1981, 58, 454-460.

77. Matus, A.; Slinkard, A.E.; Vandenberg, A. The potential of zero tannin lentil. In New Crops; Janick, J., Simon, J.E., Eds.; Wiley: New York, NY, USA, 1993; pp. 279-282.

78. Mirali, M.; Purves, R.W.; Stonehouse, R.; Song, R.; Bett, K.; Vandenberg, A. Genetics and biochemistry of zero-tannin lentils. PLoS ONE 2016, 11, e0164624. [CrossRef] [PubMed]

79. Savage, G.P. Antinutritional factors in peas. In Recent Advances of Research in Antinutritional Factors in Legume Seeds; Huisman, J., van der Poel, T.F.B., Liener, I.E., Eds.; Centre for Agricultural Publishing and Documentation: Wageningen, The Netherlands, 1989; pp. 342-350.

80. Liener, I.E.; Kakade, M.L. Protease inhibitors. In Toxic Constituents in Plant Feedstuff; Liener, I.E., Ed.; Academic Press: New York, NY, USA, 1980; pp. 7-71.

81. Pisulewska, E.; Pisulewski, P.M. Trypsin inhibitor activity of legume seed (peas, chickling vetch, lentils, and soya beans) as affected by the technique of harvest. Anim. Feed Sci. Technol. 2000, 86, 261-265. [CrossRef]

82. Norton, G. Proteinase inhibitors. In Toxic Substances in Crop Plants; D’Mello, J.P.F., Duffus, C.M., Duffus, J.H., Eds.; The Royal Society of Chemistry: Cambridge, UK, 1991; pp. 68-106.

83. Bhatty, R.S. Trypsin inhibitor activity in faba bean (Vicia faba var. minor), changes during germination and distribution. Can. J. Plant Sci. 1977, 57, 979-982. [CrossRef]

84. Elkowicz, K.; Sosulski, F.W. Antinutritional factors in eleven legumes and their air-classified protein and starch fractions. Food Sci. 1982, 47, 1301-1304. [CrossRef]

85. Shi, L.; Mu, K.; Arntfield, S.D.; Nickerson, M.T. Changes in levels of enzyme inhibitors during soaking and cooking for pulses available in Canada. J. Food Sci. Technol. 2017, 54, 1014-1022. [CrossRef]

86. Zinselmeier, C.; Jeong, B.R.; Boyer, J.S. Starch and the control of kernel number in maize at low water potentials. Plant Physiol. 1999, 121, 25-35. [CrossRef]

87. Gooding, M.J.; Ellis, R.H.; Shewry, P.R.; Schofield, J.D. Effects of restricted water availability and increased temperature on the grain filling, drying and quality of winter wheat. J. Cereal Sci. 2003, 37, 295-309. [CrossRef]

88. Rakszegi, M.; Darkó, E.; Lovegrove, A.; Molnár, I.; Láng, L.; Bedő, Z.; Molnár-Láng, M.; Shewry, P. Drought stress affects the protein and dietary fiber content of wholemeal wheat flour in wheat/Aegilops addition lines. PLoS ONE 2019, 14, e0211892. [CrossRef] [PubMed]

89. Behboudian, M.H.; Ma, Q.; Turner, N.C.; Palta, J.A. Reactions of chickpea to water stress: Yield and seed composition. J. Sci. Food Agric. 2001, 81, 1288-1291. [CrossRef]

90. Dornbos, D.L.; Mullen, R.E. Soybean seed protein and oil contents and fatty acid composition adjustments by drought and temperature. J. Am. Oil Chem. Soc. 1992, 69, 228-231. [CrossRef]

91. Mertz-Henning, L.M.; Ferreira, L.C.; Henning, F.A.; Mandarino, J.M.G.; Santos, E.D.; Oliveira, M.C.N.D.; Nepomuceno, A.E.L.; Farias, J.R.B.; Neumaier, N. Effect of water deficit-induced at vegetative and reproductive stages on protein and oil content in soybean grains. Agronomy 2018, 8, 3. [CrossRef] 
92. Sehgal, A.; Sita, K.; Siddique, K.H.M.; Kumar, R.; Bhogireddy, S.; Varshney, R.K.; HanumanthaRao, B.; Nair, R.M.; Prasad, P.V.V.; Nayyar, H. Drought or/and heat-stress effects on seed filling in food crops: Impacts on functional biochemistry, seed yields, and nutritional quality. Front. Plant Sci. 2018, 9, 1705. [CrossRef] [PubMed]

93. Sita, K.; Sehgal, A.; Bhandari, K.; Kumar, J.; Kumar, S.; Singh, S.; Siddique, K.H.M.; Nayyar, H. Impact of heat stress during seed filling on seed quality and seed yield in lentil (Lens culinaris Medikus) genotypes. J. Sci. Food Agric. 2018, 98, 5134-5141. [CrossRef]

94. Liu, T.; Staden, J. Partitioning of carbohydrates in salt-sensitive and salt-tolerant soybean cultures under salinity stress and its subsequent relief. Plant Growth Regul. 2001, 33, 13-17. [CrossRef]

95. Zhao, H.; Dai, T.; Jiang, D.; Cao, W. Effects of high temperature on key enzymes involved in starch and protein formation in grains of two wheat cultivars. J. Agron. Crop Sci. 2008, 194, 47-54. [CrossRef]

96. Mossé, J.; Huet, J.C.; Baudet, J. The amino acid composition of wheat grain as a function of nitrogen content. J. Cereal Sci. 1985, 3, 115-130. [CrossRef]

97. Lizarazo, C.I.; Lampi, A.M.; Liu, J.; Sontag-Strohm, T.; Piironen, V.; Stoddard, F.L. Nutritive quality and protein production from grain legumes in a boreal climate. J. Sci. Food Agric. 2015, 95, 2053-2064. [CrossRef] [PubMed]

98. Warsame, A.; O'Sullivan, D.M.; Tosi, P. Seed storage proteins of faba bean (Vicia faba L): Current status and prospects for genetic improvement. J. Agric. Food Chem. 2018, 66, 12617-12626. [CrossRef] [PubMed]

99. Ivanov, N.N. The causes of chemical variability in the seeds of chickpea in different geographical areas. In Monograph of the Genius; Quoted in Van der Maesen, 1972; Cicer, L.A., Ed.; Agriculture University Communication: Wageningen, The Netherlands, 1933.

100. Khatun, A.M.; Bhuiyan, A.H.; Dey, T.K. Nitrogen uptake and protein yield in lentil as influenced by seed collection from different parts of plants. Bangladesh J. Agric. Res. 2010, 35, 515-523. [CrossRef]

101. Ali-Khan, S.T. Seed yield, seed weight, percent protein and protein yield of field peas as affected by seeding dates. Can. J. Plant Sci. 1977, 57, 17-20. [CrossRef]

102. Karjalainen, R.; Hovinen, S. Variation in protein content of peas under Finnish conditions. J. Sci. Agric. Soc. Finl. 1981, 53, 228-238. [CrossRef]

103. Krotz, L.; Ciceri, E.; Giazzi, G. Protein Determination in Cereals and Seeds. Food Quality and Safety. 2008. Available online: http/Foodqualityandsafety.com (accessed on 2 September 2019).

104. Moore, J.C.; de Vries, W.; Lipp, M.; Grifiths, J.C.; Abernethy, D.R. Total protein methods and their potential utility to reduce the risk of food protein adulteration. Compr. Rev. Food Sci. Food Saf. 2010, 9, 330-351. [CrossRef]

105. FAO. Pulses. 2016. Available online: www.fao.com (accessed on 2 September 2019).

106. Mihaljev, A.Ž.; Jakšić, M.S.; Prica, N.B.; Ćupić, Ž.N.; Živkov-Baloš, M. Comparison of the Kjeldahl method, Dumas method and NIR method for total nitrogen determination in meat and meat products. J. Agro Proc. Technol. 2015, 21, 365-370.

107. Subedi, M.; Willenborg, C.J.; Vandenberg, A. Influence of harvest aid herbicides on seed germination, seedling vigor and milling quality traits of red lentil (Lens culinaris L.). Front. Plant Sci. 2017, 8, 311. [CrossRef] [PubMed]

108. Swanson, B.G. Pea and lentil protein extraction and functionality. J. Am. Oil Chem. Soc. 1990, 67, $276-279$. [CrossRef]

109. Aryee, A.N.A.; Boye, J.I. Improving the digestibility of lentil flours and protein isolate and characterization of their enzymatically prepared hydrolysates. Int. J. Food Prop. 2016, 19, 2649-2665. [CrossRef]

110. Joshi, M.; Timilsena, Y.; Adhikari, B. Global production, processing and utilization. J. Integr. Agric. 2017, 16, 2898-2913. [CrossRef]

111. Vose, J.R. Production and functionality of starches and protein isolates form legume seeds (field peas and horsebeans). Cereal Chem. 1980, 57, 406-410.

112. Gueguen, J. Legume seed protein extraction, processing, and end product characteristics. Plant Foods Hum. Nutr. 1993, 32, 267-303. [CrossRef]

113. Tyler, R.T.; Youngs, C.G.; Sosulski, F.W. Air classification of legumes. 1. Separation efficiency, yield, and composition of the starch and protein fractions. Cereal Chem. 1981, 58, 144-148.

114. Reichert, R.D. Quantitative isolation and estimation of cell wall material from dehulled pea (Pisum sativum) flours and concentrates. Cereal Chem. 1981, 58, 266-270. 
115. Lee, H.C.; Htoon, A.K.; Uthayakumaran, S.; Paterson, J.L. Chemical and functional quality of protein isolated from alkaline extraction of Australian lentil cultivars: Matilda and Digger. Food Chem. 2007, 102, 1199-1207. [CrossRef]

116. Fan, T.Y.; Sosulski, F.W. Dispersibility and isolation of proteins from legume flours. Can. Inst. Food Sci. Technol. J. 1974, 7, 256-259. [CrossRef]

117. Alsohaimy, S.A.; Sitohy, M.Z.; El-Masry, R.A. Isolation and partial characterization of chickpea, lupine and lentil seed proteins. World J. Agric. Sci. 2007, 3, 123-129.

118. Joshi, M.; Adhikari, B.; Aldred, P.; Panozzo, J.F.; Kasapis, S. Physicochemical and functional properties of lentil protein isolates prepared by different drying methods. Food Chem. 2011, 129, 1513-1522. [CrossRef]

119. Joshi, M.; Adhikari, B.; Aldred, P.; Panozzo, J.F.; Kasapis, S.; Barrow, C.J. Interfacial and emulsifying properties of lentil protein isolate. Food Chem. 2012, 134, 1343-1353. [CrossRef]

120. Kaur, M.; Singh, N.; Sandhu, K.S. Preparation and characterization of protein isolates from different lentil (Lens culinaris) cultivars. J. Food Sci. Technol. 2007, 44, 327-329.

121. Johnston, S.P.; Nickerson, M.T.; Nicholas, H.L. The physicochemical properties of legume protein isolates and their ability to stabilize oil-in-water emulsions with and without genipin. J. Food Sci. Technol. 2015, 52, 4135-4145. [CrossRef] [PubMed]

122. Jarpa-Parra, M.; Bamdad, F.; Wang, Y.; Tian, Z.; Temelli, F.; Han, J.; Chen, L. Optimization of lentil protein extraction and the influence of process $\mathrm{pH}$ on protein structure and functionality. LWT Food Sci. Technol. 2014, 57, 461-469. [CrossRef]

123. Matsusaka, S.; Maruyama, H.; Matsuyama, T.; Ghadiri, M. Triboelectric charging of powders: A review. Chem. Eng. Sci. 2010, 65, 5781-5807. [CrossRef]

124. Jafari, M.; Rajabzadeh, A.R.; Tabtabaei, S.; Marsolais, F.; Legge, R.L. Physicochemical characterization of a navy bean (Phaseolus vulgaris) protein fraction produced using a solvent-free method. Food Chem. 2016, 208, 35-41. [CrossRef]

125. Assatory, A.; Vitellia, M.; Rajabzdeh, A.R.; Legge, R.L. Dry fractionation methods for plant protein, starch and fiber enrichment: A review. Trends Food Sci. Technol. 2019, 86, 340-351. [CrossRef]

126. Tabtabaei, S.; Jafari, M.; Rajabzadeh, A.R.; Legge, R.L. Solvent-free production of protein-enriched fractions from navy bean flour using a triboelectrification-based approach. J. Food Eng. 2016, 174, 21-28. [CrossRef]

127. Tabtabaei, S.; Konakbayeva, D.; Rajabzadeh, A.R.; Legge, R.L. Analysis of protein enrichment during singleand multi-stage triboelectrostatic bioseparation processes for dry fractionation of legume flour. Sep. Purif. Technol. 2017, 176, 48-58. [CrossRef]

128. Tabtabaei, S.; Konakbayeva, D.; Rajabzadeh, A.R.; Legge, R.L. Functional properties of navy bean (Phaseolus vulgaris) protein concentrates obtained by pneumatic tribo-electrostatic separation. Food Chem. 2019, 283, 101-110. [CrossRef]

129. Udenigwe, C.C.; Aluko, R.E. Food protein-derived bioactive peptides: Production, processing, and potential health benefits. J. Food Sci. 2012, 77, R11-R24. [CrossRef]

130. Garcia-Mora, P.; Peñas, P.; Frias, J.; Martinez-Villaluenga, C. Savinase, the most suitable enzyme for releasing peptides from lentil (Lens culinaris var. castellana) protein concentrates with multifunctional properties. J. Agric. Food Chem. 2014, 62, 4166-4174. [CrossRef]

131. Barbana, C.; Boye, J.I. Angiotensin I-converting enzyme inhibitory properties of lentil protein hydrolysates: Determination of the kinetics of inhibition. Food Chem. 2011, 127, 94-101. [CrossRef]

132. Natesh, R.; Schwager, S.L.; Sturrock, E.D.; Acharya, K.R. Crystal structure of the human angiotensin-converting enzyme-Lysinopril complex. Nature 2003, 421, 551-554. [CrossRef] [PubMed]

133. García-Mora, P.; Martín-Martínez, M.; Bonache, M.A.; González-Múniz, R.; Peñas, E.; Frias, J.; Martinez-Villaluenga, C. Identification, functional gastrointestinal stability and molecular docking studies of lentil peptides with dual antioxidant and angiotensin I converting enzyme inhibitory activities. Food Chem. 2017, 221, 464-472. [CrossRef] [PubMed]

134. Wu, J.; Aluko, R.E.; Nakai, S. Structural requirements of angiotensin I converting enzyme inhibitory peptides: Quantitative structure-activity relationship study of di and tripeptides. J. Agric. Food Chem. 2006, 54, 732-738. [CrossRef]

135. Rizzello, C.B.; Verni, M.; Bordignon, S.; Gramaglia, V.; Gobbetti, M. Hydrolysate from a mixture of legume flours with antifungal activity as an ingredient for prolonging the shelf-life of wheat bread. Food Microbiol. 2017, 64, 72-82. [CrossRef] 
136. Wang, H.X.; Ng, T.B. An antifungal peptide from red lentil seeds. Peptides 2007, 28, 547-552. [CrossRef]

137. Chalamaiah, M.; Ulug, S.K.; Hong, H.; Wu, J. Regulatory requirements of bioactive peptides (protein hydrolysates) from food proteins. J. Funct. Foods 2019, 58, 123-129. [CrossRef]

138. Mamilla, R.K.; Mishra, V.K. Effect of germination on antioxidant and ACE inhibitory activities of legumes. LWT Food Sci. Technol. 2017, 75, 51-58. [CrossRef]

139. Boschin, G.; Scigliuolo, G.M.; Resta, D.; Arnoldi, A. ACE-inhibitory activity of enzymatic protein hydrolysates from lupin and other legumes. Food Chem. 2014, 145, 34-40. [CrossRef] [PubMed]

140. Jakubczyk, A.; Baraniak, B. Activities and sequences of the angiotensin I-converting enzyme (ACE) inhibitory peptides obtained from the digested lentil (Lens culinaris) globulins. Int. J. Food Sci. Technol. 2013, 48, 2363-2369. [CrossRef]

141. Akıllıoglu, H.G.; Karakaya, S. Effects of heat treatment and in vitro digestion on the Angiotensin converting enzyme inhibitory activity of some legume species. Eur. Food Res. Technol. 2009, 229, 915-921. [CrossRef]

142. Pelgrom, P.J.M.; Boom, R.M.; Schutyser, M.A.I. Method development to increase protein enrichment during dry fractionation of starch-rich legumes. Food Bioprocess Technol. 2015, 8, 1495-1502. [CrossRef]

143. Ladjal-Ettoumi, Y.; Boudries, H.; Chibane, M.; Romero, A. Pea, chickpea and lentil protein isolates: Physicochemical characterization and emulsifying properties. Food Biophys. 2016, 11, 43-51. [CrossRef]

144. Can Karaca, A.; Low, N.; Nickerson, M. Emulsifying properties of chickpea, faba bean, lentil and pea proteins produced by isoelectric precipitation and salt extraction. Food Res. Int. 2011, 444, 2742-2750. [CrossRef]

145. Boye, J.I.; Roufik, S.; Pesta, N.; Barbana, C. Angiotensin I-converting enzyme inhibitory properties and SDS-PAGE of red lentil protein hydrolysates. Food Sci. Technol. 2010, 43, 987-991. [CrossRef]

146. Chang, C.; Tu, S.; Ghosh, S.; Nickerson, M.T. Effects of $\mathrm{pH}$ on the inter-relationships between the physicochemical, interfacial and emulsifying properties for pea, soy, lentil and canola protein isolates. Food Res. Int. 2015, 77, 360-367. [CrossRef]

147. Primozic, M.; Duchek, A.; Nickerson, M.T.; Ghosh, S. Formation, stability and in vitro digestibility of nanoemulsions stabilized by high-pressure homogenized lentil protein isolates. Food Hydrocoll. 2018, 77, 126-141. [CrossRef]

148. Gumus, C.E.; Decker, E.A.; Mc Clements, D.J. Impact of legume protein type and location on lipid oxidation in fish oil-in-water emulsions: Lentil, peas and faba bean proteins. Food Res. Int. 2017, 100, 175-185. [CrossRef]

149. Aryee, A.N.A.; Boye, J.I. Comparative study of the effects of processing on the nutritional, physicochemical and functional properties of lentil. J. Food Proc. Preserv. 2017, 41, e12824. [CrossRef]

150. Toews, R.; Wang, N. Physicochemical and functional properties of protein concentrates from pulses. Food Res. Int. 2013, 52, 445-451. [CrossRef]

151. Stantiall, S.E.; Dale, K.J.; Calizo, F.S.; Serventi, L. Applications of pulses cooking water as functional ingredients: The foaming and gelling abilities. Eur. Food Res. Technol. 2018, 244, 97-104. [CrossRef]

152. Chang, C.; Stone, A.K.; Green, R.; Nickerson, M.T. Reduction of off-flavours and the impact on the functionalities of lentil protein isolate by acetone, ethanol, and isopropanol treatments. Food Chem. 2019, 277, 84-95. [CrossRef] [PubMed]

153. Shariati-Ievari, S.; Ryland, D.; Edel, A.; Nicholson, T.; Suh, M.; Aliani, M. Sensory and physicochemical studies of thermally micronized chickpea (Cicer arietinum) and green lentil (Lens culinaris) flours as binders in low-fat beef burgers. J. Food Sci. 2016, 81, S1230-S1242. [CrossRef] [PubMed]

154. Ma, Z.; Boye, J.I.; Azarnia, S.; Simpson, B.K. Volatile flavor profile of Saskatchewan grown pulses as affected by different thermal processing treatments. Int. J. Food Prop. 2016, 19, 2251-2271. [CrossRef]

155. Eckert, E.; Wismer, W.; Waduthanthiri, K.; Babii, O.; Yang, J.; Chen, L. Application of barley-and lentil-protein concentrates in the production of protein-enriched doughnuts. J. Am. Oil Chem. Soc. 2018, 95, 1027-1040. [CrossRef]

156. Jarpa-Parra, M.; Wong, L.; Wismer, W.; Temelli, F.; Han, J.; Huang, W.; Eckhart, E.; Tian, Z.; Shi, K.; Sun, T.; et al. Quality characteristics of angle3 food cake and muffin using lentil protein as egg/milk replacer. Int. J. Food Sci. Technol. 2017, 52, 1604-1613. [CrossRef]

157. Han, J.; Janz, J.A.M.; Gerlat, M. Development of gluten-free cracker snacks using pulse flours and fractions. Food Res. Int. 2010, 43, 627-633. [CrossRef]

158. Baugreet, S.; Kery, J.P.; Botinestean, C.; Allen, P.; Hamill, R.M. Development of novel fortified beef patties with added functional protein ingredients for elderly. Meat Sci. 2016, 122, 40-47. [CrossRef] 
159. Baugreet, S.; Kerry, J.P.; Brodkorb, A.; Gomex, C.; Auty, M.; Allen, P.; Hamill, R.M. Optimisation of plant protein and transglutaminase content in novel beef restructured steaks for older adults by central composite design. Meat Sci. 2018, 142, 65-77. [CrossRef]

160. Ma, Z.; Boye, J.I.; Simpson, B.K. Preparation of salad dressing emulsions using lentil, chickpea and pea protein isolates: A response surface methodology study. J. Food Qual. 2016, 39, 274-291. [CrossRef]

161. Primozic, M.; Duchek, A.; Nickerson, M.T.; Ghosh, S. Effect of lentil protein isolate concentration on the formation, stability and rheological behavior of oil-in-water nanoemulsions. Food Chem. 2017, 234, 65-74. [CrossRef] [PubMed]

162. Chang, C.; Nickerson, M.T. Stability and in vitro release behaviour of encapsulated omega fatty acid-rich oils in lentil protein isolate-based microcapsules. Int. J. Food Sci. Nutr. 2018, 69, 12-23. [CrossRef] [PubMed]

163. Chang, C.; Varankovich, N.; Nickerson, M.T. Microencapsulation of canola oil by lentil protein isolate-based wall materials. Food Chem. 2016, 212, 264-273. [CrossRef] [PubMed]

164. Boyaci, D.; Yemenicioglu, A. Expanding horizons of active packaging: Design of consumer-controlled release systems helps risk management of susceptible individuals. Food Hydrocoll. 2018, 79, 291-300. [CrossRef]

165. Tam, N.; Oguz, S.; Aydogdu, A.; Sumnu, G.; Sahin, S. Influence of solution properties and pH on the fabrication of electro spun lentil flour/HPMC blend nanofibers. Food Res. Int. 2017, 102, 616-624. [CrossRef] [PubMed]

(C) 2019 by the authors. Licensee MDPI, Basel, Switzerland. This article is an open access article distributed under the terms and conditions of the Creative Commons Attribution (CC BY) license (http://creativecommons.org/licenses/by/4.0/). 